\title{
Ruthenium piano-stool complexes bearing imidazole-based PN ligands
}

Kunz, Peter C ; Thiel, Indre ; Noffke, Anna Louisa ; Reiss, Guido J ; Mohr, Fabian ; Spingler, Bernhard

\begin{abstract}
A variety of piano-stool complexes of cyclopentadienyl ruthenium(II) with imidazole-based PN ligands have been synthesized starting from the precursor complexes $\mathrm{CpRu}(\mathrm{C} 10 \mathrm{H} 8)] \mathrm{PF} 6, \mathrm{CpRu}(\mathrm{NCMe})(3)] \mathrm{PF} 6$ and $\mathrm{CpRu}(\mathrm{PPh} 3)(2) \mathrm{Cl}$. PN ligands used are imidazol-2-yl, -4-yl and -5-yl phosphines. Depending on the ligand and precursor different types of coordination modes were observed; in the case of polyimidazolyl PN ligands these were kappa P-1-monodentate, kappa P-2,N-, kappa N-2,N- and kappa N-3,N,N-chelating and mu-kappa P:kappa N-2,N-brigding. The solid-state structures of $\mathrm{CpRu}(1 \mathrm{a})(2) \mathrm{Cl}]$ center dot $\mathrm{H} 2 \mathrm{O}(5$ center dot H2O) and $\mathrm{CpRu}($ mu-kappa(2)-N,N-kappa('1)-P-2b)(2)](C6H5PO3H)(2)(C6H5PO3H2)( 2), a hydrolysis product of the as well determined $\mathrm{CpRu}(2 \mathrm{~b})(2)](\mathrm{PF} 6)(2)$ center dot $2 \mathrm{CH}(3) \mathrm{CN}$ (7b center dot $2 \mathrm{CH}(3) \mathrm{CN})$ were determined $(1 \mathrm{a}=$ imidazol-2-yldiphenyl phosphine, $2 \mathrm{~b}=$ bis(1-methylimidazol-2-yl) phenyl phosphine, $3 \mathrm{a}=$ tris(imidazol-2-yl) phosphine). Furthermore, the complexes $\mathrm{CpRu}(\mathrm{L})(2)] \mathrm{PF} 6(\mathrm{~L}$ = imidazol-2-yl or imidazol-4-yl phosphine) have been screened for their catalytic activity in the hydration of 1-octyne. (C) 2011 Elsevier B. V. All rights reserved.
\end{abstract}

DOI: https://doi.org/10.1016/j.jorganchem.2011.10.006

Posted at the Zurich Open Repository and Archive, University of Zurich

ZORA URL: https://doi.org/10.5167/uzh-65336

Journal Article

Accepted Version

Originally published at:

Kunz, Peter C; Thiel, Indre; Noffke, Anna Louisa; Reiss, Guido J; Mohr, Fabian; Spingler, Bernhard (2012). Ruthenium piano-stool complexes bearing imidazole-based PN ligands. Journal of Organometallic Chemistry, 697(1):33-40.

DOI: https://doi.org/10.1016/j.jorganchem.2011.10.006 


\title{
Ruthenium Piano-Stool Complexes Bearing Imidazole-Based PN Ligands
}

\section{Peter C. Kunz ${ }^{*, a}$, Indre Thiel, ${ }^{a, b}$ Anna Louisa Noffke, ${ }^{a, c}$ Guido J. Reiß, ${ }^{a, *}$ Fabian Mohr ${ }^{d, \not}$ and Bernhard Spingler ${ }^{e, t}$}

[a] Institut für Anorganische Chemie und Strukturchemie, Heinrich-Heine-Universität, Universitätsstr. 1, D-40225 Düsseldorf, Germany, Fax: +49 211 8112287, E-mail: peter.kunz@uni-duesseldorf.de

[b] Current address: Leibniz-Institut für Katalyse e.V. an der Universität Rostock, Albert-Einstein-Str. 29a, D-18059 Rostock, Germany.

[c] Current address: Department of Chemistry, University of Warwick, Gibbet Hill Road, Coventry, CV4 7AL, UK.

[d] Bergische Universität Wuppertal, Fachbereich C - Anorganische Chemie, Gaußstr. 20, D-42119 Wuppertal, Germany.

[e] Anorganisch-Chemisches Institut, Universität Zürich-Irchel, Winterthurerstr. 190, CH-8057 Zürich, Switzerland.

[†] X-ray structure analysis.

\begin{abstract}
A variety of piano-stool complexes of cyclopentadienyl ruthenium(II) with imidazole-based PN ligands have been synthesized starting from the precursor complexes $\left[\mathrm{CpRu}\left(\mathrm{C}_{10} \mathrm{H}_{8}\right)\right] \mathrm{PF}_{6},\left[\mathrm{CpRu}(\mathrm{NCMe})_{3}\right] \mathrm{PF}_{6}$ and $\left[\mathrm{CpRu}\left(\mathrm{PPh}_{3}\right)_{2} \mathrm{Cl}\right]$. PN ligands used are imidazol-2-yl, -4-yl and -5-yl phosphines.

Depending on the ligand and precursor different types of coordination modes were observed; in the case of polyimidazolyl PN ligands these were $\kappa^{1} P$-monodentate, $\kappa^{2} P, N-, \kappa^{2} N, N$ - and $\kappa^{3} N, N, N$-chelating and $\mu-\kappa P: \kappa^{2} N, N$-brigding. The solid-state structures of $\left[\mathrm{CpRu}(\mathbf{1 a})_{2} \mathrm{Cl}\right] \mathrm{H}_{2} \mathrm{O}\left(\mathbf{5} \cdot \mathrm{H}_{2} \mathrm{O}\right)$ and $\left[\left\{\mathrm{CpRu}\left(\mu-\kappa^{2}-N, N-\right.\right.\right.$ $\left.\left.\left.\kappa^{\prime 1}-P-\mathbf{2 b}\right)\right\}_{2}\right]\left(\mathrm{C}_{6} \mathrm{H}_{5} \mathrm{PO}_{3} \mathrm{H}\right)_{2}\left(\mathrm{C}_{6} \mathrm{H}_{5} \mathrm{PO}_{3} \mathrm{H}_{2}\right)_{2}$, a hydrolysis product of the as well determined $\left[\{\mathrm{CpRu}(\mathbf{2 b})\}_{2}\right]\left(\mathrm{PF}_{6}\right)_{2} \cdot 2 \mathrm{CH}_{3} \mathrm{CN}\left(\mathbf{7 b} 2 \mathrm{CH}_{3} \mathrm{CN}\right)$ were determined (1a = imidazol-2-yldiphenyl phosphine, $\mathbf{2 b}=$ bis(1-methylimidazol-2-yl)phenyl phosphine, $\mathbf{3 a}=$ tris(imidazol-2-yl)phosphine). Furthermore, the complexes $\left[\mathrm{CpRu}(\mathrm{L})_{2}\right] \mathrm{PF}_{6}(\mathrm{~L}=$ imidazol-2-yl or imidazol-4-yl phosphine) have been screened for their catalytic activity in the hydration of 1-octyne.
\end{abstract}

Keywords: Ruthenium / PN Ligands / Imidazole / Phosphine / Imidazolylphosphine 


\section{Introduction}

The addition of water to alkynes is an important step in the synthesis of carbonyl compounds and has a long history going back as far as 1860, when Berthelot discovered the hydration of acetylene in sulfuric acid. ${ }^{1}$ One of the longest known reactions to catalyze the hydration of alkynes is the reaction with mercury(II) salts. ${ }^{2,3,4}$ Even though mercury is extremely hazardous, this reaction is still the favoured process for industrial application because it is reliable and produces good yields. ${ }^{5}$ Other metal-based catalysts which catalyze the Markovnikov as well as anti-Markovnikov hydration include $\mathrm{NaAuCl}_{4}$, $\mathrm{RuCl}_{3}$ and $[\mathrm{Ru}(\mathrm{III})(\mathrm{EDTA}-\mathrm{H}) \mathrm{Cl}], \mathrm{RhCl}_{3}, \mathrm{PtCl}_{4}$ and the Zeise dimer $\left[\left\{\mathrm{PtCl}_{3}\left(\mathrm{CH}_{2}=\mathrm{CH}_{2}\right)\right\}_{2}\right]$, just to name a few. ${ }^{6,7,8,9,10,11,12,13}$ Besides these homogenous catalysts also heterogenous catalyst systems are used. ${ }^{14,15,16}$

The first ruthenium(II) complex to be known to catalyze the anti-Markovnikov hydration was a phosphine complex described by Tokunaga and Wakatsuki. ${ }^{17,18}$ The catalytic activity as well as the selectivity of ruthenium(II) depends on the nature of the phosphine ligands. ${ }^{19}$ Using $\mathrm{PPh}_{2}\left(\mathrm{C}_{6} \mathrm{~F}_{5}\right)$ and $\mathrm{P}\left(3-\mathrm{C}_{6} \mathrm{H}_{4} \mathrm{SO}_{3} \mathrm{Na}\right)_{3}$ as ligands leads to selective anti-Markovnikov addition of water and satisfactory yields of the aldehyde. However, these catalytic systems involve a high catalyst/metal loading and yield only moderate turnovers and selectivity. Using cyclopentadienyl ruthenium(II) complexes with monodentate or bidentate phosphine ligands provides an increased catalytic activity as well as selectivity towards the anti-Markovnikov product, e.g. $[\mathrm{CpRu}(\mathrm{dppm}) \mathrm{Cl}](\mathrm{dppm}=$ bis(diphenylphosphino)methane) gives the anti-Markovnikov product in excellent yield while tolerating a wide spectrum of substrates. ${ }^{20}$

Nature uses proteins as polyfunctional ligands, which show multiple interactions between the enzyme and either substrate, intermediate(s), or transition state(s) during the catalytic cycle. ${ }^{3}$ For example, the tungsteno enzyme acetylene hydratase of Pelobacter acetylenicus uses acetylene as the sole carbon source, which is converted to acetaldehyde and then used by the enzyme to build acetic acid and ethanol, important building blocks for the bacteria's metabolism. ${ }^{21,22,23,24}$ While enzymes are impressive, their structures are complex, and due to their high level of specificity for particular conversions, they are only of minor use for the development of generally efficient catalysts.

More recently, phosphine ligands containing heterocyclic substituents such as pyridinyl or imidazolyl groups were investigated in bifunctional catalysis. ${ }^{25,26,27,2829}$ By modification of the pyridine ring the reactivity and catalytic activity of the corresponding complexes can be tuned. ${ }^{30}$ Grotjahn suggested that the nitrogen heterocycle acts as a bifunctional acid/base catalyst, initiating the protonation of the alkyne and leading to the ruthenium(IV) vinylidene species. ${ }^{31}$ 
In this report we investigated the hydration of terminal alkynes catalyzed by $\mathrm{CpRu}(\mathrm{II})$ compounds containing different imidazolyl phosphines as potentially bifunctional PN ligands. The imidazol-2-yl and imidazol-4-yl phosphine ligands employed bear substituents of varying steric demand. Also included were selected bis and tris(imidazolyl)phosphine ligands.

\section{Experimental Section}

\subsection{Synthesis}

Compounds $\mathbf{1 a , b}, \mathbf{d}-\mathbf{3 a}, \mathbf{b}, \mathbf{d}^{32,33}$ and $\mathbf{1 h}^{34}$ as well as $\left[\mathrm{CpRu}\left(\mathrm{PPh}_{3}\right)_{2} \mathrm{Cl}\right]^{35}$ and $\left[\mathrm{CpRu}\left(\mathrm{C}_{10} \mathrm{H}_{8}\right)\right] \mathrm{PF}_{6}{ }^{36}$ were prepared according to literature procedures. All reactions were carried out in Schlenk tubes under an atmosphere of dry nitrogen using anhydrous solvents purified according to standard procedures. All chemicals were purchased from commercial sources and used as received. ${ }^{1} \mathrm{H}$ and ${ }^{31} \mathrm{P}$ NMR spectra were recorded on a Bruker DRX 200 spectrometer. The ${ }^{1} \mathrm{H}$ spectra were calibrated against the residual proton signal of the solvent as an internal reference $\left(\mathrm{CDCl}_{3}: \delta_{\mathrm{H}}=7.30 \mathrm{ppm}\right.$; methanol- $d_{4}: \delta_{\mathrm{H}}=3.31$ ppm; acetone- $d_{6}: \delta_{\mathrm{H}}=2.05 \mathrm{ppm}$, acetonitrile- $\left.d_{3}: \delta_{\mathrm{H}}=1.94 \mathrm{ppm}\right)$ while the ${ }^{31} \mathrm{P}\left\{{ }^{1} \mathrm{H}\right\}$ NMR spectra were referenced to external $85 \% \mathrm{H}_{3} \mathrm{PO}_{4}$. The ESI mass spectra were recorded on a Finnigan LCQ Deca ion trap API mass spectrometer. The MALDI mass spectra were recorded on a Bruker Ultraflex MALDITOF mass spectrometer. The FAB mass spectra were recorded on a Finnigan MAT 8200 mass spectrometer using a nitrobenzylic alcohol (NBA) matrix. Infrared spectra were recorded with a Bruker IFS 66 FT-IR spectrometer. The elemental composition of the compounds was determined with a Perkin Elmer Analysator 2400 at the Institut für Pharmazeutische und Medizinische Chemie, Heinrich-Heine Universität Düsseldorf.

\subsubsection{Synthesis of 1-methyl-4,5-diphenylimidazole-2-yl-diphenylphosphine (2-MIP $\left.{ }^{\text {diPh-NMe }}, 1 \boldsymbol{c}\right)$}

1-Methyl-4,5-diphenylimidazole $(2 \mathrm{~g}, 8 \mathrm{mmol})$ is placed in a Schlenk tube equipped with a magnetic stirring bar and dissolved in dry thf $(100 \mathrm{~mL})$. At $-78^{\circ} \mathrm{C} n$-butyllithium $(5.3 \mathrm{~mL}, 1.6 \mathrm{M}$ in hexane $)$ is added slowly to the solution, which turns deep red. The reaction mixture is stirred at $-78{ }^{\circ} \mathrm{C}$ for $1 \mathrm{~h}$ until the diphenylchlorophosphine $(1.6 \mathrm{~mL}, 8.0 \mathrm{mmol})$ is slowly added to the solution, which turns yellow and is then stirred over night at room temperature. The solvent is removed and the residue is dissolved in with ammonia-saturated dichloromethane. This solution is stirred over night and the white solid is filtered off. The solvent is removed from the filtrate yielding the product as a white-yellow solid, which is dried under vacuum. Yield $2.00 \mathrm{~g}(60 \%)$. ${ }^{1} \mathrm{H}$ NMR $\left(200 \mathrm{MHz}, \mathrm{CDCl}_{3}\right): \delta=3.57\left(\mathrm{~s}, 3 \mathrm{H}, \mathrm{CH}_{3}\right), 7.15-$ $7.74(\mathrm{~m}, 20 \mathrm{H}, \mathrm{Ph}) .{ }^{31} \mathrm{P}\left\{{ }^{1} \mathrm{H}\right\} \mathrm{NMR}\left(200 \mathrm{MHz}, \mathrm{CDCl}_{3}\right): \delta=-28.74$ (s); ESI (methanol): $m / z=419$ $\left[\mathrm{M}^{+}+\mathrm{H}\right], 341\left[\mathrm{M}^{+}-\mathrm{Ph}\right] ; \mathrm{C}_{28} \mathrm{H}_{23} \mathrm{~N}_{2} \mathrm{P}^{2} /{ }_{3} \mathrm{CH}_{2} \mathrm{Cl}_{2}$ (475.49): calc. C 72.5, H 5.2, N 5.9; found C 72.6, H 5.3, N 5.5 . 


\subsubsection{Synthesis of 2-tert-butylimidazole-4(5)-yl-diphenylphosphine $\left(4-M I P^{t B u}, \mathbf{1 e}\right)$}

1-Methoxymethyl-2-tert-butylimidazole $(1.3 \mathrm{~g}, 8.0 \mathrm{mmol})$ is placed in a Schlenk tube equipped with a magnetic stirring bar and dissolved in dry thf $(100 \mathrm{~mL})$. At $-78{ }^{\circ} \mathrm{C}$ tert-butyllithium $(5.3 \mathrm{~mL}, 1.6 \mathrm{M}$ in hexane) is added slowly to the solution, which turns deep red. The reaction mixture is stirred at $-78^{\circ} \mathrm{C}$ for $1 \mathrm{~h}$ until the diphenylchlorophosphine $(1.6 \mathrm{~mL}, 8.0 \mathrm{mmol})$ is slowly added to the solution, which turns yellow and is then stirred over night at room temperature. The solvent is removed and the residue is dissolved in with ammonia-saturated dichloromethane. This solution is stirred over night and the white solid is filtered off. The solvent is removed from the filtrate and the residue dissolved in acetone/water $(10: 1)$ and $2 \mathrm{~mL}$ of conc. hydrochloric acid added. The mixture is refluxed for 4 hours, all volatiles removed in vacuo and the residue dissolved in a minimum amount of ethanol and sodium hydroxide solution added. The precipitate is filtered off, washed with diethyl ether and dried in vacuo. Yield: $1.06 \mathrm{~g}$ (43 \%). ${ }^{1} \mathrm{H}$ NMR (200 MHz, $\left.\mathrm{CDCl}_{3}\right): \delta=1.34\left(\mathrm{~s}, 9 \mathrm{H}, \mathrm{CH}_{3}\right), 6.91 \mathrm{~Hz}\left(\mathrm{~s}, \mathrm{H}_{\mathrm{im}}\right), 7.25-7.35$ $(\mathrm{m}, 10 \mathrm{H}, \mathrm{Ph}), 10.80$ (very broad, $1 \mathrm{H}, \mathrm{NH}) .{ }^{31} \mathrm{P}\left\{{ }^{1} \mathrm{H}\right\}$ NMR $\left(81 \mathrm{MHz}, \mathrm{CDCl}_{3}\right): \delta=-31.0 . \mathrm{ESI}^{+}$ (methanol): $m / z(\%)=309[\mathrm{M}+\mathrm{H}]^{+}(100), 249[\mathrm{M}-t \mathrm{Bu}]^{+}$(95). $\mathrm{C}_{19} \mathrm{H}_{21} \mathrm{~N}_{2} \mathrm{P} \cdot 5 / 3 \mathrm{H}_{2} \mathrm{O}$ (308.36): calc. C 67.44, H, 7.23, N 8.27; found C 67.49, H 6.90, N 8.14.

\subsubsection{Synthesis of 2-phenylimidazole-4(5)-yldiphenylphosphine $\left(4-M I P^{P h}, \mathbf{1 f}\right)$}

1-Methoxymethyl-2-phenylimidazole $(1.5 \mathrm{~g}, 8.0 \mathrm{mmol})$ is placed in a Schlenk tube equipped with a magnetic stirring bar and dissolved in dry thf $(100 \mathrm{~mL})$. At $-78{ }^{\circ} \mathrm{C}$ tert.-butyllithium $(5.3 \mathrm{~mL}, 1.6 \mathrm{M}$ in hexane) is added slowly to the solution, which turns deep red. The reaction mixture is stirred at $-78{ }^{\circ} \mathrm{C}$ for $1 \mathrm{~h}$ until the diphenylchlorophosphine $(1.6 \mathrm{~mL}, 8.0 \mathrm{mmol})$ is slowly added to the solution, which turns yellow and is then stirred over night at room temperature. The solvent is removed and the residue is dissolved in with ammonia-saturated dichloromethane. This solution is stirred over night and the white solid is filtered off. The solvent is removed from the filtrate and the residue (which is the protected phosphine, ${ }^{1} \mathrm{H}$ NMR $\left(200 \mathrm{MHz} \mathrm{CDCl}_{3}\right): \delta=3.23\left(\mathrm{~s}, 3 \mathrm{H}, \mathrm{OCH}_{3}\right), 5.40\left(\mathrm{~d}, J=1.5 \mathrm{~Hz}, \mathrm{CH}_{2}\right)$, $\left.6.86 \mathrm{~Hz}\left(\mathrm{~s}, \mathrm{H}_{\mathrm{im}}\right), 7.33-7.85(\mathrm{~m}, 15 \mathrm{H}, \mathrm{Ph}) .{ }^{31} \mathrm{P}\left\{{ }^{1} \mathrm{H}\right\} \mathrm{NMR}\left(81 \mathrm{MHz}, \mathrm{CDCl}_{3}\right): \delta=-34.0\right)$ dissolved in acetone/water $(10: 1)$ and $2 \mathrm{~mL}$ of conc. Hydrochloric acid added. The mixture is refluxed for 4 hours, all volatiles removed in vacuo and the residue dissolved in a minimum amount of ethanol and sodium hydroxide solution added. The precipitate is filtered off, washed with diethyl ether and dried in vacuo. Yield: $1.39 \mathrm{~g}(53 \%) .{ }^{1} \mathrm{H}$ NMR $\left(200 \mathrm{MHz}, \mathrm{CDCl}_{3}\right): \delta=6.71 \mathrm{~Hz}\left(\mathrm{~s}, 1 \mathrm{H}, \mathrm{H}_{\mathrm{im}}\right), 7.15-8.00(\mathrm{~m}, 15 \mathrm{H}, \mathrm{Ph})$ $8.44\left(\mathrm{~s}, 1 \mathrm{H}, \mathrm{H}_{\mathrm{im}}\right), 15.17(\mathrm{~s}$, broad, $1 \mathrm{H}, \mathrm{NH}) .{ }^{31} \mathrm{P}\left\{{ }^{1} \mathrm{H}\right\}$ NMR $\left(81 \mathrm{MHz}, \mathrm{CDCl}_{3}\right): \delta=-29.8$. ESI MS (methanol): $m / z$ (rel. int.) $=386(100)[\mathrm{M}+\mathrm{NaCl}]^{+}, 329(15)[\mathrm{M}+\mathrm{H}]^{+} \cdot \mathrm{C}_{21} \mathrm{H}_{17} \mathrm{~N}_{2} \mathrm{P} \cdot \mathrm{C}_{2} \mathrm{H}_{5} \mathrm{OH}(374.42)$ : calc. C 73.78, H, 6.19, N 7.48; found C 73.85, H 5.50, N 7.02. 


\subsubsection{Synthesis of 1-methyl-2-isopropylimidazole-4-yldiphenylphosphine (4-MIP $\left.{ }^{i P r, N M e}, 1 i\right)$}

1-Methyl-4-iodo-2-isopropylimidazole (1 g, $4 \mathrm{mmol})$ is dissolved in dichloromethane. One equivalent of ethyl magnesium bromide ( $3 \mathrm{M}$ in ether) is slowly added to the solution at $0{ }^{\circ} \mathrm{C}$. The clear solution is stirred for $30 \mathrm{~min}$ at room temperature before the diphenylchlorophosphine $(0.75 \mathrm{~mL}, 4.0 \mathrm{~mol}$ [are $0.75 \mathrm{ml}$ really 4 mol??]) is added. The solution is stirred at room temperature over night. The solvent is removed and the soft solid is redissolved in ammonia-saturated dichloromethane and stirred over night. A white solid precipitates which is filtered off. The solvent of the filtrate is removed, yielding a whiteyellow solid, which is then stirred in ethanol under addition of $1 \mathrm{~mL}$ of hydrochloric acid. The solvent is removed and the solid stirred in ammonia-saturated dichloromethane. The precipitated white solid is removed by filtration and the solvent of the filtrate is removed, resulting in a white powder, which is dried under vacuum. Yield $0.71 \mathrm{~g}(58 \%) .{ }^{1} \mathrm{H}$ NMR $\left(200 \mathrm{MHz}\right.$, methanol- $\left.d_{4}\right): \delta=1.34\left(\mathrm{~d}, 6 \mathrm{H}, \mathrm{CH}_{3}\right)$, $3.19(\mathrm{~m}, 1 \mathrm{H}, \mathrm{CH}), 3.63\left(\mathrm{~s}, 3 \mathrm{H}, \mathrm{CH}_{3}\right), 6.56(\mathrm{~s}, 1 \mathrm{H}, \mathrm{CH}), 7.36-7.84(\mathrm{~m}, 10 \mathrm{H}, \mathrm{Ph}) ;{ }^{31} \mathrm{P}\left\{{ }^{1} \mathrm{H}\right\} \mathrm{NMR}(81$ MHz, methanol- $d_{4}$ ): $\delta=-24.44$ (s); EI MS (methanol): $m / z=308\left[\mathrm{M}^{+}\right] \cdot \mathrm{C}_{19} \mathrm{H}_{21} \mathrm{~N}_{2} \mathrm{P} \cdot \mathrm{H}_{2} \mathrm{O}$ (326.15): calc. C 66.50, H 6.70, N 9.83; found C 66.88, H 6.68, N 10.04.

\subsubsection{Synthesis of 1-methyl-2-tert-butylimidazole-4-yldiphenylphosphine (4-MIP $\left.P^{t B u, N M e}, \mathbf{1 j}\right)$}

1-Methyl-4-iodo-2-tert-butylimidazole (1.2 g, $45 \mathrm{mmol})$ is dissolved in dichloromethane. One equivalent of ethyl magnesium bromide ( $3 \mathrm{M}$ in ether) is slowly added to the solution at $0{ }^{\circ} \mathrm{C}$. The clear solution is stirred for $30 \mathrm{~min}$ at $0^{\circ} \mathrm{C}$ and another $30 \mathrm{~min}$ at room temperature before the diphenylchloro phosphine $(0.82 \mathrm{~mL}, 4.5 \mathrm{~mol}$ [see question above]) is added. The solution is stirred at room temperature over night. The solvent is removed and the solid is redissolved in ammonia-saturated dichloromethane and stirred over night. A white solid precipitates which is filtered off. The solvent of the filtrate is removed, yielding a white-yellow solid, which is then stirred in ethanol under addition of $1 \mathrm{~mL}$ of hydrochloric acid. The solvent is removed and the solid stirred in ammonia-saturated dichloromethane. The precipitated white solid is removed by filtration and the solvent of the filtrate is removed, resulting in a white powder, which is dried under vacuum. The solid is recrystallized from acetone and dried under vacuum. The product was yielded as $\mathrm{MgBr}_{2}$ adduct. Yield $0.88 \mathrm{~g}(42 \%)$. ${ }^{1} \mathrm{H} \mathrm{NMR}(200 \mathrm{MHz}$, $\left.\mathrm{CDCl}_{3}\right): \delta=1.67\left(\mathrm{~s}, 9 \mathrm{H}, \mathrm{CH}_{3}\right), 3.91\left(\mathrm{~s}, 3 \mathrm{H}, \mathrm{CH}_{3}\right), 6.34(\mathrm{~s}, 1 \mathrm{H}, \mathrm{CH}), 7.42-8.09(\mathrm{~m}, 10 \mathrm{H}, \mathrm{Ph}) .{ }^{31} \mathrm{P}\left\{{ }^{1} \mathrm{H}\right\}$ $\operatorname{NMR}\left(81 \mathrm{MHz}, \mathrm{CDCl}_{3}\right.$ ): $\delta=-30.48$ (s). MS ESI (methanol): $m / z=527\left[\mathrm{LMgBr}_{2}+\mathrm{Na}\right]^{+}(15)$. $\mathrm{C}_{20} \mathrm{H}_{23} \mathrm{~N}_{2} \mathrm{PMgBr}_{2} \mathrm{NH}_{3}$ (523.53): calc. C 45.88, H 5.01, N 8.03; found C 45.15, H 5.75, N 7.65.

\subsubsection{Synthesis of imidazole-2-yl-phenylphosphine $\left(2-B I P^{H}, 2 a\right)$}

A solution of n-butyl lithium in $n$-hexane $(1.6 \mathrm{M}, 12 \mathrm{~mL}, 19 \mathrm{mmol})$ was added drop-wise to a solution of $3.0 \mathrm{~g}(18 \mathrm{mmol})$ of 1-diethoxymethylimidazole in diethyl ether $(150 \mathrm{~mL})$ at $-78^{\circ} \mathrm{C}$. The reaction mixture was stirred at $-40^{\circ} \mathrm{C}$ for $1 \mathrm{~h}$ and then was cooled to $-78^{\circ} \mathrm{C}$ and $\mathrm{PCl}_{3}(1.56 \mathrm{~g}, 8.72 \mathrm{mmol})$ was 
added. The reaction mixture was stirred at $-78^{\circ} \mathrm{C}$ for $1 \mathrm{~h}$ and at ambient temperature over night. Concentrated ammonia solution $(5 \mathrm{~mL})$ was added, the phases separated, the organic phase was collected and all volatiles were removed in vacuo. The oily residue was dissolved in $100 \mathrm{~mL}$ acetone/water (10:1) and stirred at ambient temperature for $72 \mathrm{~h}$. The resulting precipitate was collected by filtration and dried in vacuo. Yield: $1.1 \mathrm{~g}(52 \%)$. ${ }^{1} \mathrm{H}$ NMR (methanol- $\left.d_{4}\right): \delta=7.27-7.35(\mathrm{~m}, 9 \mathrm{H})$. ${ }^{31} \mathrm{P}\left\{{ }^{1} \mathrm{H}\right\}$ NMR (methanol- $\left.d_{4}\right): \delta=-46(\mathrm{~s}) . \mathrm{ESI}^{+}$(methanol): $m / z(\%)=243[\mathrm{~L}]^{+} . \mathrm{C}_{12} \mathrm{H}_{11} \mathrm{~N}_{4} \mathrm{P} \cdot \mathrm{CH}_{3} \mathrm{OH}$ (274.26): calc. C 56.93, H 5.51, N 20.43; found C 56.4, H 5.6, N 20.7.

\subsubsection{Synthesis of $\left[C p R u(\kappa P-1 d)\left(P P h_{3}\right) C l\right](4)$}

$\left[\mathrm{CpRu}\left(\mathrm{PPh}_{3}\right)_{2} \mathrm{Cl}\right](0.5 \mathrm{~g}, 0.69 \mathrm{mmol})$ and $1 \mathrm{~d}(0.17 \mathrm{~g}, 0.67 \mathrm{mmol})$ were heated for $4 \mathrm{~h}$ in toluene to reflux. The volatiles were removed in vacuo and the residue treated with $n$-hexane to give a yellow solid. After filtration the product was chromatographed on silica $\left(\mathrm{CH}_{2} \mathrm{Cl}_{2}: n\right.$-hexane $3: 1$, followed by $\left.\mathrm{CH}_{2} \mathrm{Cl}_{2}\right)$. Yield $52 \mathrm{mg}(10 \%)$. ${ }^{1} \mathrm{H} \mathrm{NMR}\left(200 \mathrm{MHz}, \mathrm{CDCl}_{3}\right): \delta=1.20\left(\mathrm{dd},{ }^{3} J_{\mathrm{HH}}=6.9 \mathrm{~Hz},{ }^{3} J_{\mathrm{HH}}=12.9\right.$ $\left.\mathrm{Hz}, 6 \mathrm{H}, \mathrm{CH}\left(\mathrm{CH}_{3}\right)_{2}\right), 2.77\left(\mathrm{~m}, 1 \mathrm{H}, \mathrm{CH}\left(\mathrm{CH}_{3}\right)_{2}\right), 4.22\left(\mathrm{~d},{ }^{3} J_{\mathrm{HH}}=9.3 \mathrm{~Hz}, 5 \mathrm{H}, \mathrm{Cp}\right), 6.72(\mathrm{~s}, 1 \mathrm{H}, \mathrm{Im}), 6.98-$ $7.24\left(\mathrm{~m}, 15 \mathrm{H}, \mathrm{PPh}_{3}\right), 7.26-7.83(\mathrm{~m}, 11 \mathrm{H}, \mathrm{Ph}) .{ }^{31} \mathrm{P}\left\{{ }^{1} \mathrm{H}\right\} \mathrm{NMR}\left(81 \mathrm{MHz}, \mathrm{CDCl}_{3}\right): \delta=45.0\left(\mathrm{dd},{ }^{2} J_{\mathrm{PP}}=\right.$ $28.3 \mathrm{~Hz}, 43.0 \mathrm{~Hz}), 30.4\left(\mathrm{t},{ }^{2} J_{\mathrm{PP}}=21.3 \mathrm{~Hz}\right)$. MALDI-TOF-MS: $m / z$ (rel. Int.) $=755[\mathrm{M}-2 \mathrm{H}]^{+}(25), 723$ $[\mathrm{M}-\mathrm{Cl}]^{+}(100), 461\left[\mathrm{M}-\mathrm{PPh}_{3} \mathrm{Cl}\right]^{+}(25) . \mathrm{C}_{41} \mathrm{H}_{39} \mathrm{ClN}_{2} \mathrm{P}_{2} \mathrm{Ru}$ (758.29): calc. C 65.0, H 5.2, N 3.7; found C 65.1, H 4.9, N 3.7.

\subsubsection{Synthesis of $\left[\mathrm{CpRu}\left((\kappa \mathrm{P}-\mathbf{1 a})_{2} \mathrm{Cl}\right](\mathbf{5})\right.$}

$\left[\mathrm{CpRu}\left(\mathrm{PPh}_{3}\right)_{2} \mathrm{Cl}\right](100 \mathrm{mg}, 0.138 \mathrm{mmol})$ and $1 \mathrm{a}(70 \mathrm{mg}, 0.28 \mathrm{mmol})$ were heated to $90{ }^{\circ} \mathrm{C}$ for 8 hours in toluene $(15 \mathrm{~mL})$. The volatiles were removed in vacuo and the residue treated with $n$-hexane $(15 \mathrm{~mL})$. The resulting solid was filtered and dried in vacuo. Yield $61 \mathrm{mg}(63 \%) .{ }^{1} \mathrm{H} \mathrm{NMR}\left(200 \mathrm{MHz}, \mathrm{CDCl}_{3}\right): \delta$ $=4.38(\mathrm{~s}, \% \mathrm{H}, \mathrm{Cp}), 3.44(\mathrm{br}, \mathrm{NH}), 6.93(\mathrm{~s}, 2 \mathrm{H}, \mathrm{im}), 9.09-7.60(\mathrm{~m}, 22 \mathrm{H}, \mathrm{Ph}, \mathrm{im}) .{ }^{31} \mathrm{P}\left\{{ }^{1} \mathrm{H}\right\} \mathrm{NMR}(81$ $\mathrm{MHz}, \mathrm{CDCl}_{3}$ ): $\delta=31.7$ (s). MALDI-TOF-MS: $m / z$ (rel. Int.) $=671[\mathrm{M}-\mathrm{Cl}]^{+}(100), 460[\mathrm{M}-1 \mathbf{a}-\mathrm{Cl}]^{+}(25)$. $\mathrm{C}_{35} \mathrm{H}_{31} \mathrm{~N}_{4} \mathrm{P}_{2} \mathrm{ClRu}$ (706.13): calc. C 59.5, $\mathrm{H} 4.4$, N 7.9; found C 60.0, H 4.6, N 8.1.

\subsubsection{Synthesis of $\left[C p R u(\kappa P-1 d)_{2} C l\right](6)$}

$\left[\mathrm{CpRu}\left(\mathrm{PPh}_{3}\right)_{2} \mathrm{Cl}\right](0.51 \mathrm{~g}, 0.70 \mathrm{mmol})$ and $1 \mathrm{~d}(0.38 \mathrm{~g}, 1.5 \mathrm{mmol})$ were heated for $20 \mathrm{~h}$ in toluene to reflux. The volatiles were removed in vacuo and the residue treated with $n$-hexane to give a yellow solid. After filtration the product was chromatographed on silica (ethyl acetate). Crystallization from methanol $/ n$-hexane yielded $18 \mathrm{mg}(30 \%)$ of $6 .{ }^{1} \mathrm{H}$ NMR $\left(200 \mathrm{MHz}, \mathrm{CDCl}_{3}\right): \delta=1.28\left(\mathrm{dd},{ }^{3} J_{\mathrm{HH}}=6.9\right.$ $\left.\mathrm{Hz}, 14.1 \mathrm{~Hz}, 12 \mathrm{H}, \mathrm{CH}\left(\mathrm{CH}_{3}\right)_{2}\right), 2.85\left(\mathrm{sept}, 2 \mathrm{H},{ }^{3} \mathrm{~J}_{\mathrm{HH}}=6.9 \mathrm{~Hz}, \mathrm{CH}\left(\mathrm{CH}_{3}\right)_{2}\right), 4.27$ (s, 5H, C5H5), 6.75 (s, 2H, ImC5H), $7.06-7.28(\mathrm{~m}, 10 \mathrm{H}, \mathrm{Ph}), 7.35-7.80(\mathrm{~m}, 10 \mathrm{H}, \mathrm{Ph}), 11.0(\mathrm{~s}, 2 \mathrm{H}, \mathrm{ImNH}) .{ }^{31} \mathrm{P}\left\{{ }^{1} \mathrm{H}\right\} \mathrm{NMR}$ $\left(81 \mathrm{MHz}, \mathrm{CDCl}_{3}\right): \delta=26.4$ (s). MALDI-TOF-MS: $m / z$ (rel. Int.) $=755[\mathrm{M}-\mathrm{Cl}]^{+}(100), 461[\mathrm{M}-1 \mathbf{d}-\mathrm{Cl}]^{+}$ (25). $\mathrm{C}_{41} \mathrm{H}_{43} \mathrm{~N}_{4} \mathrm{P}_{2} \mathrm{ClRu}$ (790.29): calc. C 62.3, H 5.5, N 7.1; found C 62.6, H 5.1, N 7.4. 


\subsubsection{Synthesis of $\left[\left\{C p R u\left(\mu-\kappa^{2} N, N: \kappa^{, 1} P-2 a\right)\right\}_{2}\right]\left(P F_{6}\right)_{2}(7 \boldsymbol{a})$}

$50 \mathrm{mg}(0.12 \mathrm{mmol})$ of $\left[\mathrm{CpRu}\left(\mathrm{NCCH}_{3}\right)_{3}\right] \mathrm{PF}_{6}$ and $\mathbf{2 a}(0.12 \mathrm{mmol}, 36 \mathrm{mg})$ were dissolved in acetonitrile and heated to gentle reflux for 24 hours. The volatiles were removed in vacuo, the residue washed with $n$-hexane and diethyl ether and dried in vacuo. Yield: $69 \mathrm{mg}(90 \%) .{ }^{1} \mathrm{H}$ NMR (500 MHz, acetonitrile$\left.d_{3}\right): \delta=3.09$ (s, $\left.12 \mathrm{H} \mathrm{NCH}_{3}\right), 5.23$ (s, $\left.5 \mathrm{H} \mathrm{Cp}\right), 6.79$ (s, $2 \mathrm{H}$ arom. $\left.\mathrm{Im}\right), 6.95$ (t, $\left.{ }^{3} J_{\mathrm{H}, \mathrm{H}}=8.2 \mathrm{~Hz}, 1 \mathrm{H} \mathrm{Ph}\right)$, 7.13 (s, 2H arom. Im.), $7.40\left(\mathrm{t},{ }^{3} J_{\mathrm{H}, \mathrm{H}}=7.6 \mathrm{~Hz}, 1 \mathrm{H} \mathrm{Ph}\right), 7.65\left(\mathrm{t},{ }^{3} J_{\mathrm{H}, \mathrm{H}}=7.4 \mathrm{~Hz}, 1 \mathrm{H} \mathrm{Ph}\right), 7.75\left(\mathrm{t},{ }^{3} J_{\mathrm{H}, \mathrm{H}}=\right.$ $7.0 \mathrm{~Hz}, 1 \mathrm{H} \mathrm{Ph}), 8.23\left(\mathrm{t},{ }^{3} J_{\mathrm{H}, \mathrm{H}}=9.6 \mathrm{~Hz}, 1 \mathrm{H} \mathrm{Ph}\right){ }^{31} \mathrm{P}\left\{{ }^{1} \mathrm{H}\right\}$ NMR $\left(81 \mathrm{MHz}\right.$, acetonitrile- $\left.d_{3}\right): \delta=45.4(\mathrm{~s}),-$ 142.7 (sept., ${ }^{1} J_{\mathrm{PF}}=707 \mathrm{~Hz}$ ). ESI MS (methanol): $m / z$ (rel. int.) $=437(100) 1 / 2[\mathrm{M}+\mathrm{H}]^{+}, 355(15) 1 / 2[\mathrm{M}-$ $\left.\mathrm{Im}^{\mathrm{NMe}}\right]^{+}$. MALDI-TOF-MS (methanol): $m / z$ (rel. int.) $=437(100)[\mathrm{M}]^{+} . \mathrm{C}_{38} \mathrm{H}_{40} \mathrm{~N}_{8} \mathrm{~F}_{12} \mathrm{P}_{4} \mathrm{Ru}_{2}(1162.81)$ calc. C 39.3, H 3.5, N 9.6; found C 39.6, H 3.9, N 10.0.

\subsubsection{Synthesis of $\left[\left\{C p R u\left(\mu-\kappa^{2} N, N: \kappa^{\prime l} P-2 b\right)\right\}_{2}\right]\left(P F_{6}\right)_{2}(7 \boldsymbol{b})$}

$50 \mathrm{mg}(0.12 \mathrm{mmol})$ of $\left[\mathrm{CpRu}\left(\mathrm{NCCH}_{3}\right)_{3}\right] \mathrm{PF}_{6}$ and $\mathbf{2 a}(36 \mathrm{mg})$ were dissolved in acetonitrile and heated to gentle reflux for 24 hours. The volatiles were removed in vacuo, the residue washed with $n$-hexane and diethyl ether and dried in vacuo. Yield $46 \mathrm{mg}(67 \%) .{ }^{1} \mathrm{H}$ NMR (acetonitrile- $\left.d_{3}\right): \delta=4.91$ (s, 5H Cp), $6.95(\mathrm{~s}, 2 \mathrm{H} \mathrm{ImCH}), 6.99(\mathrm{~s}, 2 \mathrm{H} \mathrm{ImCH}), 7.58-7.80(\mathrm{~m}, 5 \mathrm{H} \mathrm{PPh}) .{ }^{31} \mathrm{P}\left\{{ }^{1} \mathrm{H}\right\}$ NMR (acetonitrile- $\left.d_{3}\right): \delta=$ 44.4 (s), -143.4 (hept.). MALDI-TOF-MS $\left(\mathrm{CH}_{3} \mathrm{CN}\right): m / z$ (rel. int.) = $816[\mathrm{M}]^{+}$(100), 574 (5), 468 (45), $453\left[1 / 2 \mathrm{M}+\mathrm{NCCD}_{3}\right]^{+}(30), 409\left[1 \frac{1}{2} \mathrm{M}\right]^{+}$(80). $\mathrm{C}_{36} \mathrm{H}_{35} \mathrm{~N}_{9} \mathrm{P}_{4} \mathrm{Ru}_{2} \mathrm{~F}_{12}$ (1147.75): calc. C 37.7,H 3.1, N 11.0; found C 37.5, H 3.2, N 10.7.

\subsubsection{Synthesis of $\left[C p R u\left(\kappa^{3} N, N, N-3 b\right)\right] C l(8)$}

$100 \mathrm{mg}(0.138 \mathrm{mmol})$ of $\left[\mathrm{CpRu}\left(\mathrm{PPh}_{3}\right)_{2} \mathrm{Cl}\right]$ were dissolved in warm toluene. To the clear orange solution 3a (38 mg, $0.14 \mathrm{mmol}$ ) was added. The solution was warmed to $100{ }^{\circ} \mathrm{C}$ and after $30 \mathrm{~min}$. a yellow solid precipitated. The reaction mixture was stirred at $100{ }^{\circ} \mathrm{C}$ for additional 3 hours. After cooling to ambient temperature and filtration the solid was washed with small amounts of toluene and diethyl ether and dried in vacuo. Yield: $51 \mathrm{mg}(78 \%)$. ${ }^{1} \mathrm{H}$ NMR (200 MHz, methanol- $\left.d_{4}\right): \delta=4.06$ (s, 9H, NCH3), 4.50 (s, 5H, Cp), $7.38\left(\mathrm{dd},{ }^{3} J_{\mathrm{H}, \mathrm{H}}=4.0 \mathrm{~Hz},{ }^{4} J_{\mathrm{H}, \mathrm{H}}=1.6 \mathrm{~Hz}, 3 \mathrm{H}, \operatorname{Im} H 5\right), 7.99$ (s) (d, $\left.{ }^{3} J_{\mathrm{H}, \mathrm{H}}=4.0 \mathrm{~Hz}, 3 \mathrm{H}, \operatorname{Im} H 4\right)$. ${ }^{31} \mathrm{P}\left\{{ }^{1} \mathrm{H}\right\}$ NMR (81 MHz, methanol- $\left.d_{4}\right): \delta=-116.5$ (s). MALDI TOF MS: $m / z$ (rel. Int.) $=441[\mathrm{M}-\mathrm{Cl}]^{+}$ (100). $\mathrm{C}_{17} \mathrm{H}_{22} \mathrm{~N}_{6} \mathrm{ClPRu} \cdot \mathrm{H}_{2} \mathrm{O}$ (493.90): calc. C 41.4, H 4.5, N 17.0; found C 41.7, H 4.7, N 16.7.

\subsubsection{Synthesis of $\left[C p R u(\kappa P-3 a)\left(P P h_{3}\right) C l\right](9)$}

$100 \mathrm{mg}(0.132 \mathrm{mmol})\left[\mathrm{CpRu}\left(\mathrm{PPh}_{3}\right)_{2} \mathrm{Cl}\right]$ were dissolved in $20 \mathrm{~mL}$ toluene upon gentle heating. $32 \mathrm{mg}$ $(0.13 \mathrm{mmol})$ of $\mathbf{3 a}$ were added and the solution was stirred at $70{ }^{\circ} \mathrm{C}$ for $6 \mathrm{~h}$. A greenish white solid was separated and the orange solution was subsequently reduced in vacuo. The orange residue was taken up in $2 \mathrm{~mL}$ dichloromethane. Column-chromatography on silica gel with dichloromethane and ethyl acetate respectively, gave the product as an orange solid. Yield: $55 \mathrm{mg}(57 \%){ }^{1} \mathrm{H}$ NMR (200 MHz, methanol- 
$\left.d_{4}\right): \delta=4.54$ (s, 5H, Cp), 7.08-7.34 (m, 21H, arom.). ${ }^{31} \mathrm{P}\left\{{ }^{1} \mathrm{H}\right\}$ NMR (81 MHz, methanol- $\left.d_{4}\right): \delta=46(\mathrm{~d}$, $\left.{ }^{2} J_{\mathrm{P}, \mathrm{P}}=45 \mathrm{~Hz}\right), 4\left(\mathrm{~d},{ }^{2} J_{\mathrm{P}, \mathrm{P}}=45 \mathrm{~Hz} \text { ). ESI MS (methanol): } m / z \text { (rel. int.) }=399 \text { (100) [M-PPh }{ }_{3} \mathrm{Cl}\right]^{+}$. MALDI TOF MS (methanol): $m / z$ (rel. int.) = 399 (60) $\left[\mathrm{M}-\mathrm{PPh}_{3} \mathrm{Cl}\right]^{+}, 415$ (15) $\left[\mathrm{CpRu}\left(2-\mathrm{TIPO}^{\mathrm{H}}\right)\right]^{+}$. $\mathrm{C}_{32} \mathrm{H}_{31} \mathrm{~N}_{6} \mathrm{ClP}_{2} \mathrm{Ru} \cdot 2 \mathrm{H}_{2} \mathrm{O}$ (732.12): calc. C 52.5, $\mathrm{H}$ 4.5, N 11.5; found C 52.3, H 4.6, N 11.4.

\subsection{General procedure for the catalytic hydration reaction}

$\left[\mathrm{RuCp}\left(\mathrm{C}_{10} \mathrm{H}_{8}\right)\right] \mathrm{PF}_{6}(22 \mathrm{mg}, 0.05 \mathrm{mmol})$ and the respective ligand (2.2 eq., $\left.0.11 \mathrm{mmol}\right)$ were dissolved in acetonitrile or dichloromethane, respectively. The solution was stirred at $60{ }^{\circ} \mathrm{C}$ over night. Removal of most of the solvent under vacuum and addition of diethyl ether or hexane resulted in the respective ruthenium complex as a fine yellow powder, which is dried under vacuum after filtration. This preformed, but not further purified ruthenium catalyst $(0.05 \mathrm{mmol}, 5 \mathrm{~mol} \%$ catalyst loading) was dissolved in acetone $(2 \mathrm{~mL})$ and degassed 1-octyne $(150 \mu \mathrm{L})$ and water $(90 \mu \mathrm{L})$ were added to the solution. The reaction mixture was stirred at $60{ }^{\circ} \mathrm{C}$ in an oil bath. The progress of the reaction was monitored by GC.

\subsection{X-ray crystallography}

Crystallographic data of $\quad\left[\left\{\mathrm{CpRu}\left(\mu-\kappa^{2}-N, N-\kappa^{\prime 1}-P-\mathbf{2 b}\right)_{2}\right]\left(\mathrm{C}_{6} \mathrm{H}_{5} \mathrm{PO}_{3} \mathrm{H}\right)_{2}\left(\mathrm{C}_{6} \mathrm{H}_{5} \mathrm{PO}_{3} \mathrm{H}_{2}\right)_{2}\right.$, $\left[\{\mathrm{CpRu}(\mathbf{2 b})\}_{2}\right]\left(\mathrm{PF}_{6}\right)_{2} \cdot 2 \mathrm{CH}_{3} \mathrm{CN}\left(\mathbf{7} \mathbf{b} 2 \mathrm{CH}_{3} \mathrm{CN}\right),\left[\mathrm{CpRu}(\mathbf{1 a})_{2} \mathrm{Cl}\right] \cdot \mathrm{H}_{2} \mathrm{O}\left(\mathbf{5} \mathrm{H}_{2} \mathrm{O}\right)$ and $\left[\mathrm{CpRu}\left(\mathrm{PPh}_{3}\right)_{2} \mathrm{Cl}\right] \cdot \mathrm{CHCl}_{3}$ were collected at 183(2) K on an Oxford Diffraction Xcalibur system with a Ruby detector using Mo $\mathrm{K}_{\alpha}$ radiation $(\lambda=$ $0.7107 \AA$ ) that was graphite-monochromated. Suitable crystals were covered with oil (Infineum V8512, formerly known as Paratone N), mounted on top of a glass fibre and immediately transferred to the diffractometer. The program suite CrysAlis ${ }^{\text {Pro }}$ was used for data collection, multi-scan absorption correction and data reduction. ${ }^{37}$ Structures were solved with direct methods using SIR9 $7^{38}$ and were refined by full-matrix least-squares methods on $\mathrm{F}^{2}$ with SHELXL-97. ${ }^{39}$ The structures were checked for higher symmetry with help of the program Platon. ${ }^{40}$ The crystal of $\left[\{\mathrm{CpRu}(\mathbf{2 b})\}_{2}\right]\left(\mathrm{PF}_{6}\right)_{2} 2 \mathrm{CH}_{3} \mathrm{CN}\left(\mathbf{7 b} 2 \mathrm{CH}_{3} \mathrm{CN}\right)$ is non-merohedrally twinned. The two twin domains are related by a 180 degree rotation along uvw $\left(\begin{array}{lll}0 & 0 & 1\end{array}\right)$. Both domains (ratio 52:48) were integrated with the CrysalisPro software and refined as hklf5. Yellow crystals of $5 \mathrm{H}_{2} \mathrm{O}$ were mounted on a glass fibre with a small amount of inert oil. Data collection was carried out at $100 \mathrm{~K}$ using an Oxford Diffraction Xcalibur diffractometer, equipped with an EOS CCD area detector and a four-circle kappa goniometer using Mo$\mathrm{K} \alpha$ radiation $(\lambda=0.71073 \AA$ ). Data integration, scaling and empirical absorption correction was carried out using the CrysAlis Pro program package. ${ }^{37}$ The structure of was solved using Direct Methods and refined by Full-Matrix-Least-Squares against $\mathrm{F}^{2}$. All non-hydrogen atoms positions were refined freely and simultaneously using anisotropic displacement parameters. The positional parameters of the hydrogen atoms of the $\mathrm{CH}$ groups were refined freely. The positional parameters of the hydrogen atoms of the $\mathrm{NH}$ groups were refined with soft $\mathrm{N}-\mathrm{H}$ distance restraints and individual $\mathrm{U}_{\text {iso }}$ values. The hydrogen atoms of the water molecule were refine with soft $\mathrm{O}-\mathrm{H}$ and $\mathrm{H}-\mathrm{H}$ distance restraints giving 
these hydrogen atoms a fixed isotropic displacement parameters. All calculations were carried out using the program SHELX97. Orange crystals of $\left.[\mathrm{CpRu}(\kappa)-\mathbf{3 a})\left(\mathrm{PPh}_{3}\right)\right] \mathrm{Cl}^{1} \cdot \mathrm{CH}_{2} \mathrm{Cl}_{2}\left(\mathbf{9}^{-} \mathrm{CH}_{2} \mathrm{Cl}_{2}\right)$ were mounted on a MiTeGen cryoloop with a small amount of inert oil. Data collection was carried out at $150 \mathrm{~K}$ using an Oxford Diffraction Gemini E Ultra diffractometer, equipped with an EOS CCD area detector and a four-circle kappa goniometer using Mo-K $\alpha$ radiation $(\lambda=0.71073 \AA$ ). Data integration, scaling and empirical absorption correction was carried out using the CrysAlis Pro program package. ${ }^{37}$ The structure was solved using Direct Methods and refined by Full-Matrix-Least-Squares against $\mathrm{F}^{2}$. All non-hydrogen atoms were refined anisotropically and hydrogen atoms were placed at idealised positions and refined using the riding model. All calculations were carried out using the program Olex $2 .{ }^{41}$ Important crystallographic data and refinement details are summarised in Table 4. The crystallographic data has been deposited at the CCDC with the ref codes CCDC 820763, 828860, 828861 , and 837344 . 


\section{Results and Discussion}

\subsection{Synthesis of PN ligands}

Pyridin-2-ylphosphines are privileged hemilabile PN ligands in transition metal catalysis. Also, imidazole-2-ylphosphines are well-established ligands for transition metal complexes, e.g. Grotjahn et al. recently described the ability of imidazole-2-yldiphenylphosphine to act as a hemilabile PN ligand in $\mathrm{Cp}^{*} \mathrm{Ir}$ complexes $^{42}$ and Caballero et al. observed rearrangement of 1-methylimidazole-2yldiphenylphosphine (1b) in complexes $\left[(\operatorname{arene}) \mathrm{Ru}(\mathbf{1 b}) \mathrm{Cl}_{2}\right]$ including $\mathrm{P}-\mathrm{C}$ bond cleavage in this process. ${ }^{43}$ We synthesised several series of imidazole-based phosphine ligands in the last few years for biomimetic model complexes and metallo-drugs. ${ }^{33,34,44,45,46,47}$ Here, these ligands as well as some new PN ligands, as depicted in Figure 1, were used in CpRu-complexes, which should catalyse the hydration of alkynes.
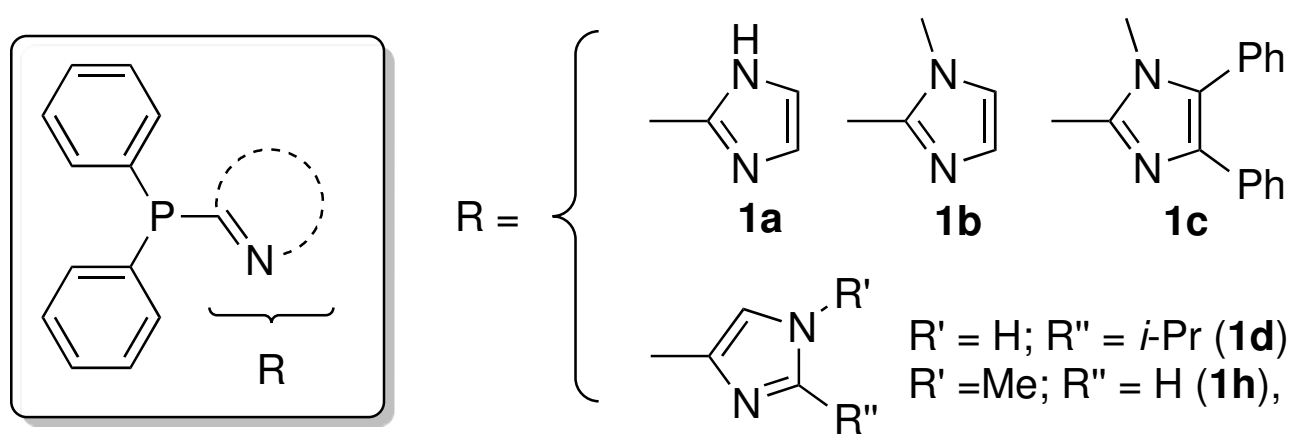<smiles>[R7]c1nc(C)cn1[Tl]</smiles>

$\mathrm{R}^{\prime}=\mathrm{H} ; \mathrm{R}^{\prime \prime}=i-\operatorname{Pr}(\mathbf{1 d}), t-\mathrm{Bu}(\mathbf{1 e}), \operatorname{Ph}(\mathbf{1 f})$

$\mathrm{R}^{\prime}=\mathrm{Me} ; \mathrm{R}^{\prime \prime}=\mathrm{H}(\mathbf{1} \mathbf{h}), i-\operatorname{Pr}(\mathbf{1 i}), t-\mathrm{Bu}(\mathbf{1 j})$

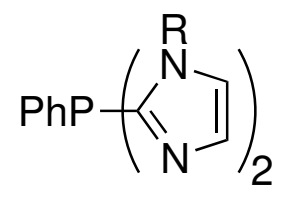

$\mathrm{R}=\mathrm{H}(\mathbf{2} \mathbf{a})$

$\mathrm{R}=\mathrm{Me}(\mathbf{2 b})$<smiles>[R]c1[nH]cnc1C</smiles>

$\mathrm{R}=\mathrm{H}(\mathbf{3} \mathbf{a})$

$\mathrm{R}=\mathrm{Me}(\mathbf{3 b})$<smiles></smiles>

2d<smiles>CC[Te]Pc1nc(C)c[nH]1</smiles>

3d

Figure 1. Imidazol-2-yl- and imidazol-4-yl-phosphine ligands used.

Especially imidazole derivatives with bulky groups such as isopropyl, phenyl or tert-butyl in orthoposition to the imine $\mathrm{N}$ atom were chosen since they are known to prevent $\kappa^{2} P N$-coordination. ${ }^{30}$ Furthermore, ligands without sterically demanding groups such as 1-methylimidazole-4-yldiphenyl phosphine (1h) were synthesized.

The reaction scheme for the synthesis of the new imidazol-4-yl phosphine ligands $\mathbf{1 h}-\mathbf{j}$ is shown in Scheme 1. The respective imidazole is converted to the 4,5 -diiodoimidazole derivative by $\mathrm{KI} / \mathrm{I}_{2}$ in basic solution. Reaction of the 4,5-diiodoimidazole derivative with methyl iodide leads to the $\mathrm{N}$-methylated imidazole derivative, which is then converted in two consecutive Grignard reactions to the respective 1methylimidazol-4-yldiphenyl phosphine. 


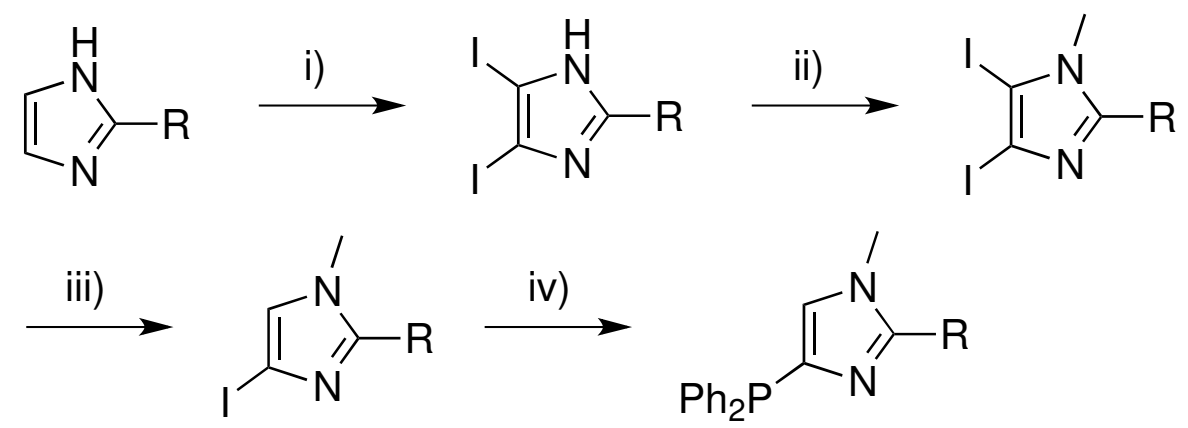

Scheme 1. General route for the synthesis of 1-methylimidazol-4-yldiphenylphosphines 1h-j (4$\mathrm{MIP}^{\mathrm{NMe}}$ s), i) $\mathrm{I}_{2} / \mathrm{KI}$ in aq. $\mathrm{NaOH}$, ii) $\mathrm{KOtBu}, \mathrm{MeI}$, thf, iii) EtMgBr, $\mathrm{H}_{2} \mathrm{O}$, thf, iv) $\mathrm{EtMgBr}_{2} \mathrm{Ph}_{2} \mathrm{PCl}$, thf.

All steps, including the first Grignard reaction, proceed in good yields, whereas the second Grignard reaction raised some problems. The product was obtained as the magnesium complex, since magnesium coordinates strongly to the imidazole $\mathrm{N}$ atom(s). This problem of magnesium adduct formation has already been addressed by Kluwer in the preparation of pyridinylphosphines. ${ }^{48}$ Repeated alternating stirring in ethanol, spiked with hydrochloric acid, or ammonia-saturated dichloromethane led to isolation of the ligands 1-methylimidazol-4-yldiphenylphosphine (1h) and 1-methy-2isopropylimidazole-4-yldiphenylphosphine (1i). In the case of 1-methyl-2-tert-butylimidazole-4yldiphenylphosphine (1j), even after repeated crystallisation from ethanol, the $\mathrm{MgBr}_{2}$ adduct was obtained.

In addition to the three 1-methylimidazol-4-yl phosphine ligands $\mathbf{1 h}-\mathbf{j}, 1$-methyl-4,5-diphenylimidazol2-yl-diphenylphosphine (1c) was synthesized as a new imidazole-2-yl ligand bearing bulky phenyl substituents (Scheme 2). The methylation of 4,5-diphenylimidazol is carried out using methyl iodide. Subsequent lithiation with $n$-butyllithium and addition of diphenylchlorophosphine leads to the 1methyl-4,5-diphenylimidazol-2-yl-diphenylphosphine ligand in very good yields. Since lithium does not coordinate as strongly to the imidazole nitrogen atoms as magnesium, the separation of the lithium salts from the ligand is easily accomplished by stirring the crude product with ammonia-saturated dichloromethane followed by filtration.

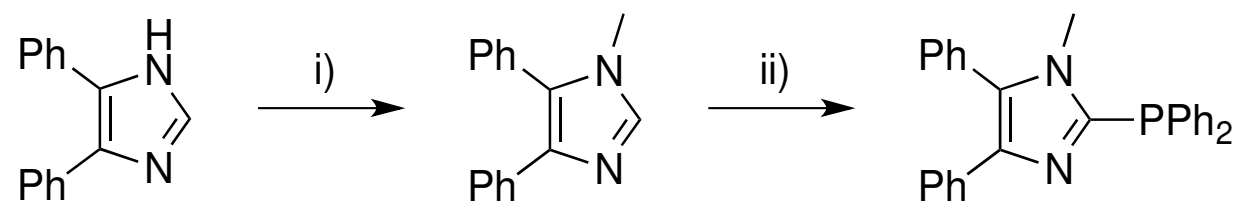

Scheme 2. Route for the synthesis of 1-Methyl-4,5-diphenylimidazol-2-yl-diphenylphosphine (2MIP ${ }^{\text {diPhNMe }}$, 1c): i) KOtBu, MeI, thf, ii) $n$-BuLi, $\mathrm{Ph}_{2} \mathrm{PCl}$, thf.

Spectroscopic data of the four new ligands $\mathbf{1} \mathbf{c}, \mathbf{h}-\mathbf{j}$ is summarized in Table 1. The chemical shifts observed in the ${ }^{31} \mathrm{P}$ NMR spectra are in the typical regime for monoimidazolyldiphenyl phosphines (MIPs). ${ }^{45,49}$ 
Table 1.Spectroscopic data of the synthesized ligands ( ${ }^{\mathrm{a}}$ in methanol- $d_{4},{ }^{\mathrm{b}}$ in $\mathrm{CDCl}_{3},{ }^{\mathrm{c}} \mathrm{Mg}$-salt).

\begin{tabular}{|c|c|c|c|}
\hline Ligand & & $\delta\left({ }^{1} \mathbf{H}\right) / \mathbf{p p m}$ & $\delta\left({ }^{31} \mathrm{P}\right) / \mathrm{ppm}$ \\
\hline \multirow[t]{2}{*}{$4-\mathrm{MIP}^{\mathrm{NMe}}$} & $(1 \mathrm{~h})^{\mathrm{a}}$ & $3.73\left(\mathrm{~s}, 3 \mathrm{H}, \mathrm{CH}_{3}\right), 6.93(\mathrm{t}, 1 \mathrm{H}, \mathrm{CH})$ & $-22.8(\mathrm{~s})$ \\
\hline & & 7.31-7.42(m, 10H, Ph), $7.80(\mathrm{t}, 1 \mathrm{H}, \mathrm{CH})$ & \\
\hline \multirow[t]{3}{*}{ 4-MIP ${ }^{\mathrm{iPr}, \mathrm{NMe}}$} & $(\mathbf{1 i})^{\mathrm{a}}$ & $1.34\left(\mathrm{~d}, 6 \mathrm{H}, \mathrm{CH}_{3}\right), 3.19(\mathrm{~m}, 1 \mathrm{H}, \mathrm{CH})$ & $-24.4(\mathrm{~s})$ \\
\hline & & $3.63\left(\mathrm{~s}, 3 \mathrm{H}, \mathrm{CH}_{3}\right), 6.56(\mathrm{~s}, 1 \mathrm{H}, \mathrm{CH})$, & \\
\hline & & 7.36-7.84 (m, 10H, Ph) & \\
\hline \multirow[t]{2}{*}{ 4-MIP ${ }^{\mathrm{tBu}, \mathrm{NMe}}$} & $(\mathbf{1} \mathbf{j})^{\mathrm{b}}$ & $1.67\left(\mathrm{~s}, 9 \mathrm{H}, \mathrm{CH}_{3}\right), 3.91\left(\mathrm{~s}, 3 \mathrm{H}, \mathrm{CH}_{3}\right)$, & $-30.4(\mathrm{bs})^{\mathrm{c}}$ \\
\hline & & $6.34(\mathrm{~s}, 1 \mathrm{H}, \mathrm{CH}), 7.42-8.09(\mathrm{~m}, 10 \mathrm{H}, \mathrm{Ph})$ & \\
\hline 2-MIP ${ }^{\mathrm{diPh}, \mathrm{NMe}}$ & $(\mathbf{1 c})^{\mathrm{b}}$ & $3.57\left(\mathrm{~s}, 3 \mathrm{H}, \mathrm{CH}_{3}\right), 7.15-7.74(\mathrm{~m}, 20 \mathrm{H}, \mathrm{Ph})$ & $-28.7(\mathrm{~s})$ \\
\hline
\end{tabular}

\subsection{Synthesis of CpRu-complexes with PN ligands}

We exemplarily investigated the basic coordination chemistry of some of the presented imidazole-based $\mathrm{PN}$ ligands towards $\mathrm{CpRu}(\mathrm{II})$. As ruthenium(II) precursor compounds we used $\left[\mathrm{CpRu}\left(\mathrm{C}_{10} \mathrm{H}_{8}\right)\right] \mathrm{PF}_{6}$, $\left[\mathrm{CpRu}(\mathrm{NCMe})_{3}\right] \mathrm{PF}_{6}$ and $\left[\mathrm{CpRu}\left(\mathrm{PPh}_{3}\right)_{2} \mathrm{Cl}\right]($ Scheme 3$)$.<smiles>Cl[Te]([Pb])([PbH2])[PbH2]</smiles><smiles>Cl[R](I)(I)c1ccccc1</smiles><smiles>CCCCCCC</smiles><smiles>Cl[R](I)(I)c1ccccc1</smiles>

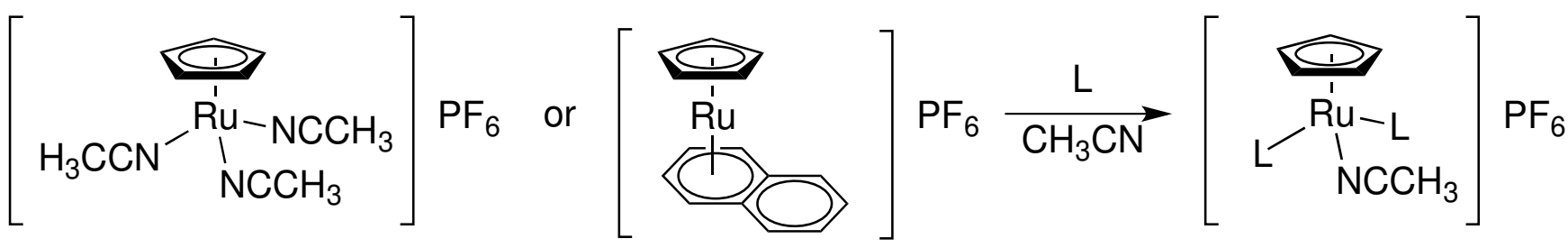

Scheme 3. Reaction of ligands (L) $\mathbf{1 a}, \mathbf{1 b}$ and $\mathbf{1 d}$ with $\left[\mathrm{CpRu}\left(\mathrm{PPh}_{3}\right)_{2} \mathrm{Cl}\right]$ and $\left[\mathrm{CpRu}\left(\mathrm{NCCH}_{3}\right)_{3}\right] \mathrm{PF}_{6}$ or $\left[\mathrm{CpRu}\left(\mathrm{C}_{10} \mathrm{H}_{8}\right)\right] \mathrm{PF}_{6}$. 
Table 2. ${ }^{31} \mathrm{P}\left\{{ }^{1} \mathrm{H}\right\}$ NMR shifts of the ligands $\left(\delta_{\mathrm{L}}\right)$ and the respective ruthenium complexes $\left(\delta_{\mathrm{C}}\right)$ as well as the coordination shift $\Delta \delta=\delta_{\mathrm{C}}-\delta_{\mathrm{L}}$ (in methanol- $\left.d_{4}\right)$.

\begin{tabular}{lccc}
\hline \multicolumn{1}{c}{$\mathbf{C p R u}\left(\mathbf{P P h}_{\mathbf{3}}\right)(\mathbf{L}) \mathbf{C l}$} & $\left.\boldsymbol{\delta}_{\mathbf{L}}{ }^{\mathbf{3 1}} \mathbf{P}\right) / \mathbf{p p m}$ & $\boldsymbol{\delta}_{\mathbf{C}}\left({ }^{\mathbf{3 1}} \mathbf{P}\right) / \mathbf{p p m}$ & $\boldsymbol{\Delta} \boldsymbol{\delta}\left({ }^{\mathbf{3 1}} \mathbf{P}\right) / \mathbf{p p m}$ \\
\hline $2-\mathrm{MIP}^{\mathrm{H}}(\mathbf{1 a})$ & -23.8 & $45.0 ; 29.3$ & 68.8 \\
$2-\mathrm{MIP}^{\mathrm{NMe}}(\mathbf{1 b})$ & -29.6 & $42.5 ; 27.6$ & 64.3 \\
$4-\mathrm{MIP}^{\mathrm{iPr}}(\mathbf{1 d})$ & -24.4 & $45.0 ; 30.4$ & 73.0 \\
\hline $\mathbf{C p R u}^{(\mathbf{L}) \mathbf{2}_{\mathbf{P}} \mathbf{P F}}$ & $\left.\boldsymbol{\delta}_{\mathbf{L}}{ }^{\mathbf{3 1}} \mathbf{P}\right) / \mathbf{p p m}$ & $\boldsymbol{\delta}_{\mathbf{C}}\left(^{\mathbf{3 1}} \mathbf{P}\right) / \mathbf{p p m}$ & $\boldsymbol{\Delta} \boldsymbol{\delta}\left({ }^{\mathbf{3}} \mathbf{P}\right) / \mathbf{p p m}$ \\
\hline $2-\mathrm{MIP}^{\mathrm{H}}(\mathbf{1 a})$ & -24.8 & 31.7 & 56.5 \\
$2-\mathrm{MIP}^{\mathrm{NMe}}(\mathbf{1 b})$ & -30.6 & 29.3 & 60.0 \\
$4-\mathrm{MIP}^{\mathrm{iPr}}(\mathbf{1 d})$ & -24.4 & 31.3 & 55.7 \\
\hline
\end{tabular}

When $\left[\mathrm{CpRu}\left(\mathrm{PPh}_{3}\right)_{2} \mathrm{Cl}\right]$ was reacted with $\mathbf{1 b}$ at room temperature for three weeks, only one $\mathrm{PPh}_{3}$ ligand was replaced by $\mathbf{1 b}$ yielding $\left[\mathrm{CpRu}\left(\mathrm{PPh}_{3}\right)(\mathbf{1 b}) \mathrm{Cl}\right]$, as is indicated by two doublets in the ${ }^{31} \mathrm{P} \mathrm{NMR}$ spectrum 
Table 2). These appeared only in small quantities in addition to signals of the starting materials and free triphenylphosphine. However, reaction of $\mathbf{1 b}$ with the more labile complex $\left[\mathrm{CpRu}\left(\mathrm{NCCH}_{3}\right)_{3}\right] \mathrm{PF}_{6}$ in dichloromethane yielded the complex $\left[\mathrm{CpRu}(\mathbf{1 b})_{2}(\right.$ solvent) $] \mathrm{PF}_{6}$ which exhibits a single singlet in the ${ }^{31} \mathrm{P}$ NMR spectrum at $38 \mathrm{ppm}$. Both ${ }^{1} \mathrm{H}$ NMR and MALDI mass spectra are also in accordance with the proposed formula. The reaction of two equivalents of $1 \mathrm{a}$ with $\left[\mathrm{CpRu}\left(\mathrm{PPh}_{3}\right)_{2} \mathrm{Cl}\right]$ below $70{ }^{\circ} \mathrm{C}$ in toluene gives $\left[\mathrm{CpRu}(\mathbf{1 a})_{2} \mathrm{Cl}\right]$ (5) by substitution of both $\mathrm{PPh}_{3}$ ligands (singlet, $\delta\left({ }^{31} \mathrm{P}\right)=31.7 \mathrm{ppm}$ ). Minor contamination of the mono-substituted complex (doublet, $\delta\left({ }^{31} \mathrm{P}\right)=45.0,29.3 \mathrm{ppm}, J=44 \mathrm{~Hz}$ ) ligands were transformed into $\left[\mathrm{CpRu}(\mathbf{1 a})_{2} \mathrm{Cl}\right](\mathbf{5})$ by addition of a slight excess of $\mathbf{1 a}$. When the reaction mixtures of $\left[\mathrm{CpRu}\left(\mathrm{PPh}_{3}\right)_{2} \mathrm{Cl}\right]$ and the $\mathrm{NH}$-ligand $1 \mathrm{a}$ were heated above $90{ }^{\circ} \mathrm{C}$, doublets at 120 and 50 ppm in the ${ }^{31} \mathrm{P}\left\{{ }^{1} \mathrm{H}\right\}$ NMR spectra were observed. The reaction with one or two equivalents of $\mathbf{1 d}$ gives $\left[\mathrm{CpRu}\left(\mathrm{PPh}_{3}\right)(\mathbf{1 d}) \mathrm{Cl}\right](\mathbf{4})$ and $\left[\mathrm{CpRu}(\mathbf{1 d})_{2} \mathrm{Cl}\right](\mathbf{6})$, respectively. For the latter we were not able to obtain a sufficient $\mathrm{CHN}$ analysis, although ${ }^{1} \mathrm{H}$ and ${ }^{31} \mathrm{P}\left\{{ }^{1} \mathrm{H}\right\}$ NMR and MALDI-TOF mass spectrometry clearly demonstrate the existence of $\left[\mathrm{CpRu}(\mathbf{1 d})_{2} \mathrm{Cl}\right](\mathbf{6})$. The compound $\left[\mathrm{CpRu}\left(\mathrm{PPh}_{3}\right)(\mathbf{1 d}) \mathrm{Cl}\right](\mathbf{4})$ shows, as expected, two signals in the ${ }^{31} \mathrm{P}$ NMR spectrum. In non-coordinating or weakly coordination solvents the resonances are found at 45 and $25 \mathrm{ppm}$ with a ${ }^{2} J_{\mathrm{PP}}$ coupling constant of $43 \mathrm{~Hz}$. In the more strongly coordination solvent methanol, which is a good solvent for the solvation of chloride, the resonances are shifted to 53 and $-5 \mathrm{ppm}$ with a coupling constant of $39 \mathrm{~Hz}$ (Table 3). Especially the high field shift of the resonance of the P-atom of the ligand 1d from about 25 to $-5 \mathrm{ppm}$ is typical for the change in the coordination mode of the ligand from $\kappa P$ to $\kappa^{2} P N .^{50}$ This can also be forced in acetone by abstraction of the chloride ligand upon addition of $\mathrm{TINO}_{3}$ (Scheme 4 and ESI).

Table 3. ${ }^{31} \mathrm{P}\left\{{ }^{1} \mathrm{H}\right\}$ NMR data of $\left[\mathrm{CpRu}\left(\mathrm{PPh}_{3}\right)(\mathbf{1 d}) \mathrm{Cl}\right](\mathbf{4})$ in different solvents.

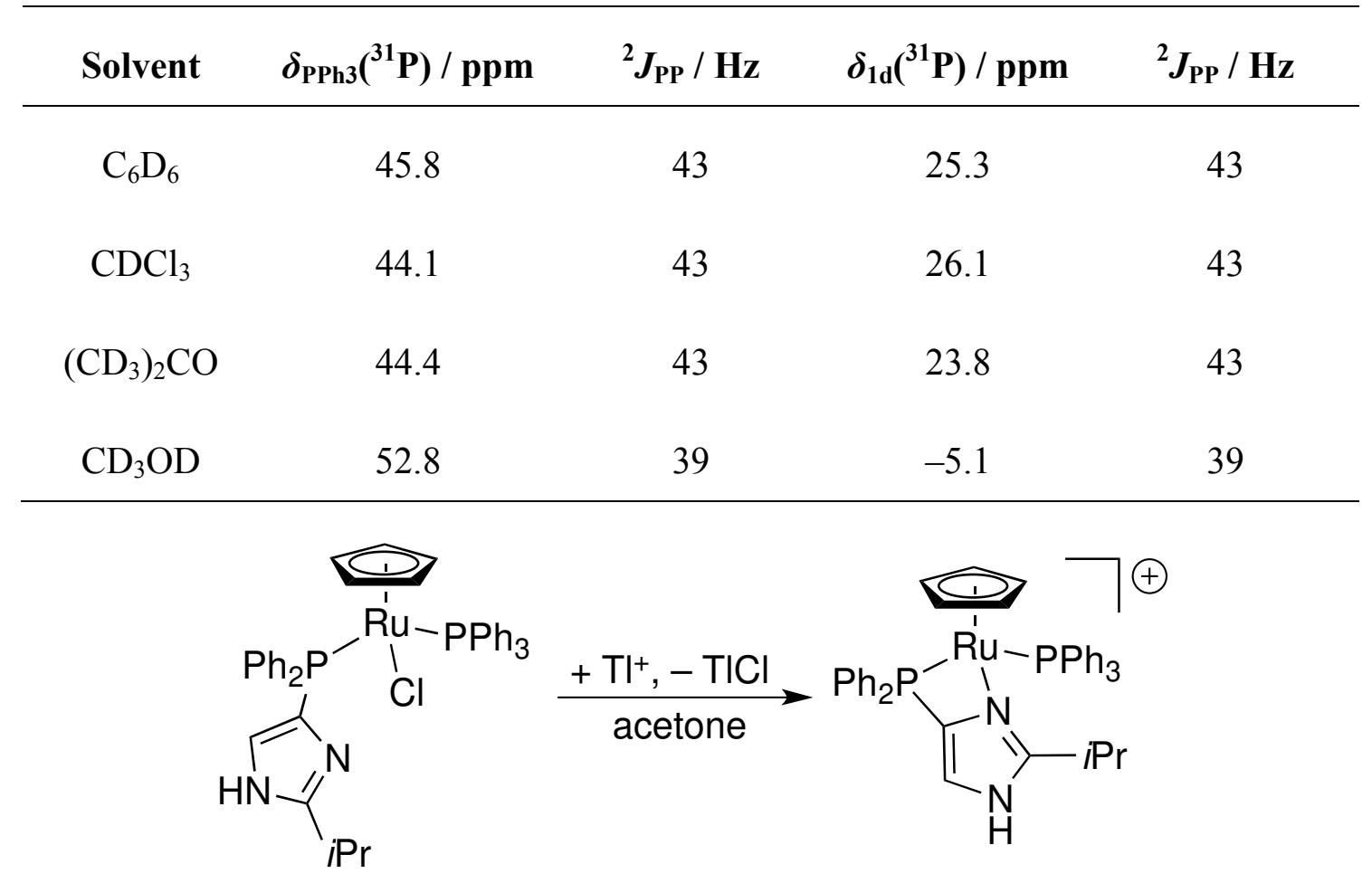

Scheme 4. Reaction of $\left[\mathrm{CpRu}\left(\mathrm{PPh}_{3}\right)(\mathbf{1 d}) \mathrm{Cl}\right](\mathbf{4})$ with $\mathrm{TlNO}_{3}$ in acetone gives a PN chelate. 
The reaction of $\mathbf{2 a}$ with $\left[\mathrm{CpRu}\left(\mathrm{PPh}_{3}\right)_{2} \mathrm{Cl}\right]$ or $\left[\mathrm{CpRu}\left(\mathrm{NCCH}_{3}\right)_{3}\right] \mathrm{PF}_{6}$ gave a single product with a singlet at $45 \mathrm{ppm}$ in the ${ }^{31} \mathrm{P}\left\{{ }^{1} \mathrm{H}\right\}$ NMR spectrum and one set of the protons of the methyl groups (singlet at 3.09 ppm), the Cp protons (singlet at $5.23 \mathrm{ppm}$ ) and the imidazolyl protons (two doublets at 6.79 and 7.13 ppm) in the ${ }^{1} \mathrm{H}$ NMR, respectively. The most intense signal in the MALDI spectrum is found at $m / z=$ 437 and shows an isotopic pattern characteristic for a compound with two ruthenium atoms and thus a charge of +2 . Additionally, a peak with small intensity is found at 874 . This is in accordance with a dimeric structure (Scheme 5), which was confirmed by single crystal analysis (see below).

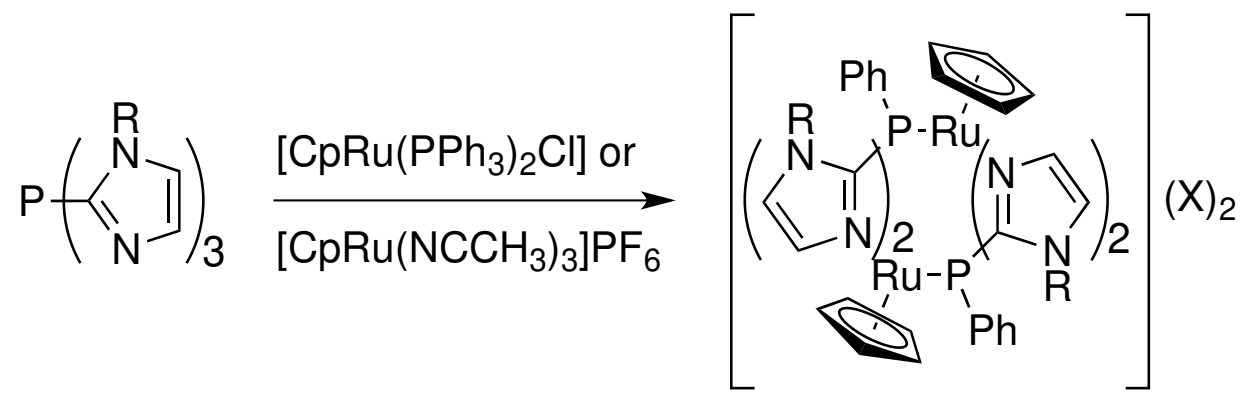

Scheme 5. Reaction of $\left[\mathrm{CpRu}\left(\mathrm{PPh}_{3}\right)_{2} \mathrm{Cl}\right]$ or $\left[\mathrm{CpRu}\left(\mathrm{NCCH}_{3}\right)_{3}\right] \mathrm{PF}_{6}$ with $2-\mathrm{BIP} \mathrm{PH}^{\mathrm{NH}}(\mathbf{2 a})$ and $2-\mathrm{BIP} \mathrm{NMe}^{\mathrm{N}}$ (2b) to complexes $7 \mathbf{a} / \mathbf{b}\left(\mathrm{X}=\mathrm{PF}_{6}\right)$.

The tripodal tetradentate ligands $\mathbf{3 a}$ and $\mathbf{3 b}$ react with $\left[\mathrm{CpRu}\left(\mathrm{PPh}_{3}\right)_{2} \mathrm{Cl}\right]$ at elevated temperatures and prolonged reaction times to complexes in which the CpRu-moiety is facially bound by the tripodal ligands in a $\kappa^{3} N, N, N$ coordination mode (Scheme 6). The coordination mode can be deduced by the typical high-field shift of the phosphorus resonance of 40 to $60 \mathrm{ppm}$ to about $-110 \mathrm{ppm}$ in $\kappa^{3} N, N, N$ complexes of these ligands.

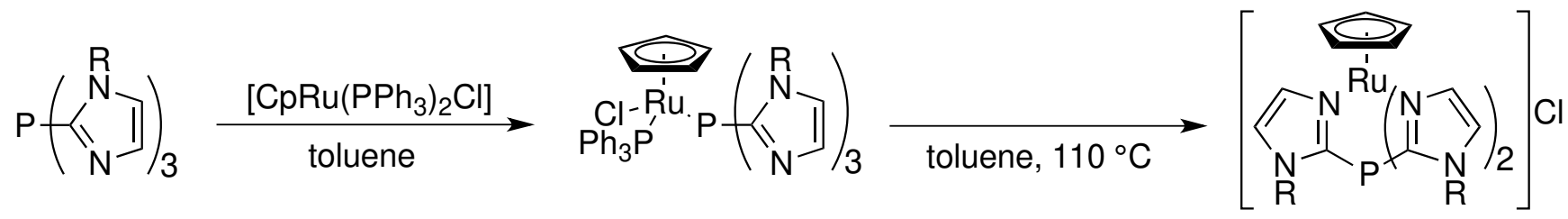

Scheme 6. Reaction of $\left[\mathrm{CpRu}\left(\mathrm{PPh}_{3}\right)_{2} \mathrm{Cl}\right]$ with $2-\mathrm{TIP}^{\mathrm{NH}}(\mathrm{R}=\mathrm{H}, \mathbf{3 a})$ and $2-\mathrm{TIP}^{\mathrm{NMe}}(\mathrm{R}=\mathrm{Me}, \mathbf{3 b})$.

At $70{ }^{\circ} \mathrm{C}$ and in the non-protic solvent toluene the reaction of $\mathbf{3 a}$ with $\left[\mathrm{CpRu}\left(\mathrm{PPh}_{3}\right)_{2} \mathrm{Cl}\right]$ leads to substitution of only one $\mathrm{PPh}_{3}$ ligand, which can easily be observed in the ${ }^{31} \mathrm{P}$ NMR spectra of the reaction mixture. Two doublets occur for the new species $\left[\mathrm{CpRu}\left(\mathrm{PPh}_{3}\right)(\mathbf{3 a}) \mathrm{Cl}\right](\mathbf{9})$ with ${ }^{2} J_{\mathrm{P}, \mathrm{P}}$ values of $\sim 50 \mathrm{~Hz}$. This product is also obtained from a reaction of the starting material with 2 equivalents of ligand 3a. Recrystallisation from chloroform yielded a crystal suitable for single crystal analysis (see below).

\subsection{Solid-state structures}


Crystals of $\left[\mathrm{CpRu}(\mathbf{1 a})_{2} \mathrm{Cl}\right] \cdot \mathrm{H}_{2} \mathrm{O}\left(\mathbf{5} \mathrm{H}_{2} \mathrm{O}\right)$ suitable for single crystal structure determination were obtained by slow evaporation of a chloroform solution at air. The $\mathrm{CpRu}$ center is coordinated octahedral by the $\eta^{5}-\mathrm{Cp}$ ligand, a chlorido ligand and two $\kappa P$-coordinated ligands $1 \mathbf{a}$. Both ligands $1 \mathrm{a}$ form $\mathrm{NH}{ }^{\cdots} \mathrm{Cl}$ hydrogen bonds towards the coordinated chlorido ligand and one is also involved in hydrogen bonding to the co-crystallised water molecule. The structural motif in $\left[\mathrm{CpRu}(\mathbf{1 a})_{2} \mathrm{Cl}\right] \cdot \mathrm{H}_{2} \mathrm{O}\left(\mathbf{5} \cdot \mathrm{H}_{2} \mathrm{O}\right)$ resembles the one found in $\left[\mathrm{CpRu}(\mathrm{L})_{2}\left(\mathrm{H}_{2} \mathrm{O}\right)\right] \mathrm{CF}_{3} \mathrm{SO}_{3}(\mathrm{~L}=1$-methyl-3-tert.butyldiphenyl phosphine $){ }^{28}$

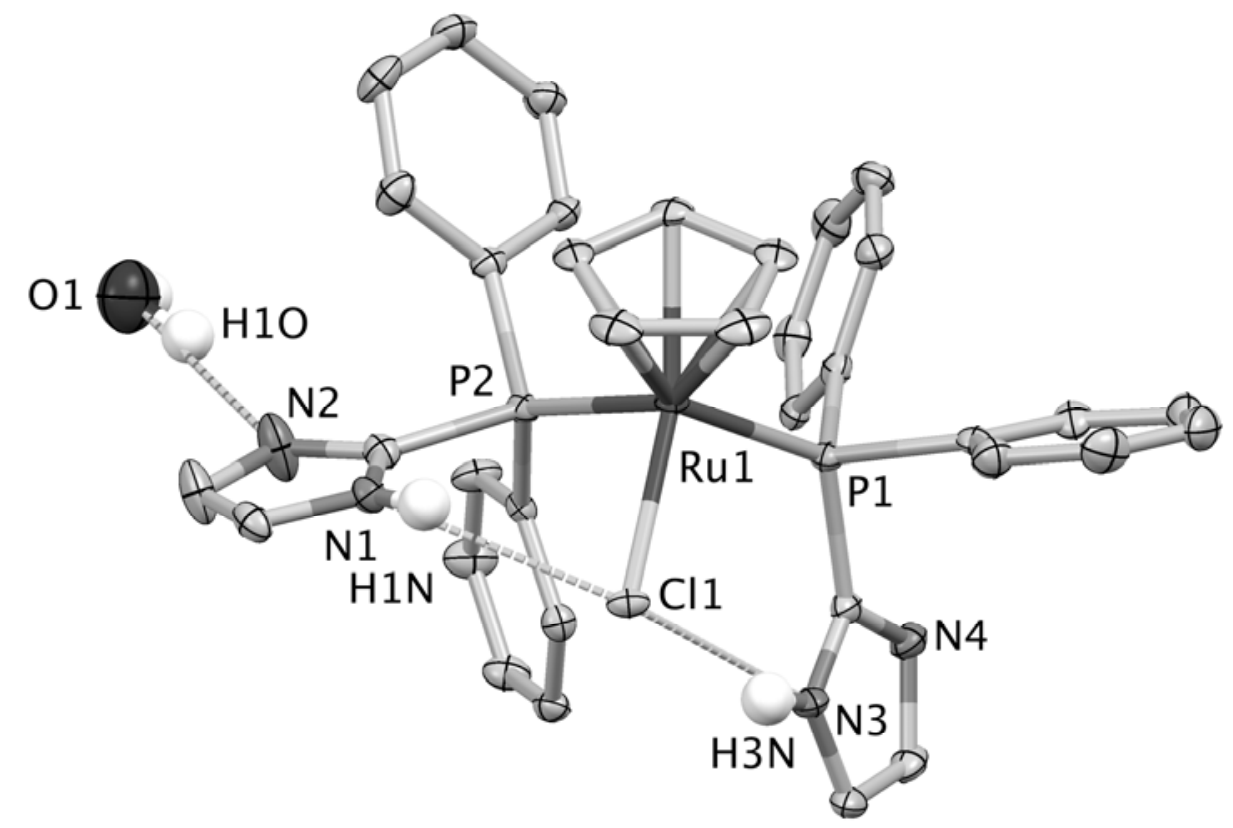

Figure 2. Solid-state structure of $\left[\mathrm{CpRu}(1 \mathbf{a})_{2} \mathrm{Cl}\right] \cdot \mathrm{H}_{2} \mathrm{O}\left(5 \cdot \mathrm{H}_{2} \mathrm{O}\right)$. Displacement ellipsoids are drawn at 50 $\%$ level. Hydrogen atoms are drawn at arbitrary radius and non-acidic hydrogen atoms are omitted for clarity.

Crystals of $\left[\left\{\mathrm{CpRu}\left(\mu-\kappa^{2} N, N: \kappa^{1} P-\mathbf{2 b}\right)\right\}_{2}\right]\left(\mathrm{PF}_{6}\right)_{2} \mathrm{CH}_{3} \mathrm{CN} \quad\left(\mathbf{7 b} \mathrm{CH}_{3} \mathrm{CN}\right)$ suitable for single crystal structure determination were obtained by slow diffusion of $n$-hexane into a solution of $\mathbf{7 b}$ in acetonitrile. Here ligand $\mathbf{2 b}$ acts as bridging ligand between two $\mathrm{CpRu}$ centers (Figure 3). Such a bridging $\mu-\kappa^{2} N, N: \kappa^{1} P$-coordination mode has tentatively been assigned to the phenylbis(pyridin-2yl)phosphine ligand $\left(\mathrm{PhPpy}_{2}\right)$ in the compound $\left[\mathrm{Mo}(\mathrm{CO})_{3}\left(\mathrm{PhPpy}_{2}\right)\right]$, which is thought to be a coordination polymer and not a cyclic dimer. ${ }^{51}$ In the $\left[\left\{\operatorname{CpRu}\left(\mu-\kappa^{2} N, N: \kappa^{1} P-\mathbf{2 b}\right)\right\}_{2}\right]^{2+}$ cation the coordination geometry of the $\mathrm{Ru}(\mathrm{II})$ atoms in the $\{\mathrm{CpRu}(\mathbf{2 b})\}$ unit is distorted octahedral with a facially bound $\eta^{5}$-Cp ligand and the $\mathrm{P}$ atom of the $\mathbf{2 b}$ ligand as well as two $\mathrm{N}$ atoms of the $\mathbf{2} \mathbf{b}$ ligand of the other unit of the $\{\mathrm{CpRu}(\mathbf{2 b})\}_{2}$ dimer. In one crystallisation experiment under non inert conditions from the reaction solution of $\left[\mathrm{CpRu}\left(\mathrm{PPh}_{3}\right)_{2} \mathrm{Cl}\right]$ together with $\mathbf{2 b}$, we found yellow crystals of $\left[\left\{\mathrm{CpRu}\left(\mu-\kappa^{2}-\right.\right.\right.$ $\left.N, N-\kappa, 1-P-\mathbf{2 b})\}_{2}\right]\left(\mathrm{C}_{6} \mathrm{H}_{5} \mathrm{PO}_{3} \mathrm{H}\right)_{2}\left(\mathrm{C}_{6} \mathrm{H}_{5} \mathrm{PO}_{3} \mathrm{H}_{2}\right)_{2}$ which crystallized in the triclinic space group $P-1$ (see ESI). Additionally, we found red crystals of a chloroform solvate of $\left[\mathrm{CpRu}\left(\mathrm{PPh}_{3}\right)_{2} \mathrm{Cl}\right]$ which crystallises in the triclinic space group $P-1$ (see ESI). Obviously, 2b partially hydrolysed under P-C bond cleavage 
and oxidized to give the phenylhydrogenphosphonate counter ion and the phenyldihydrogenphosphonate respectively. Both structures have essentially an identical cationic part. Only the cyclopentienyl and the phenyl ring are conformational slightly twisted along the ruthenium cyclopentadienyl centroid and the ispo - para atoms of the phenyl ring respectively.

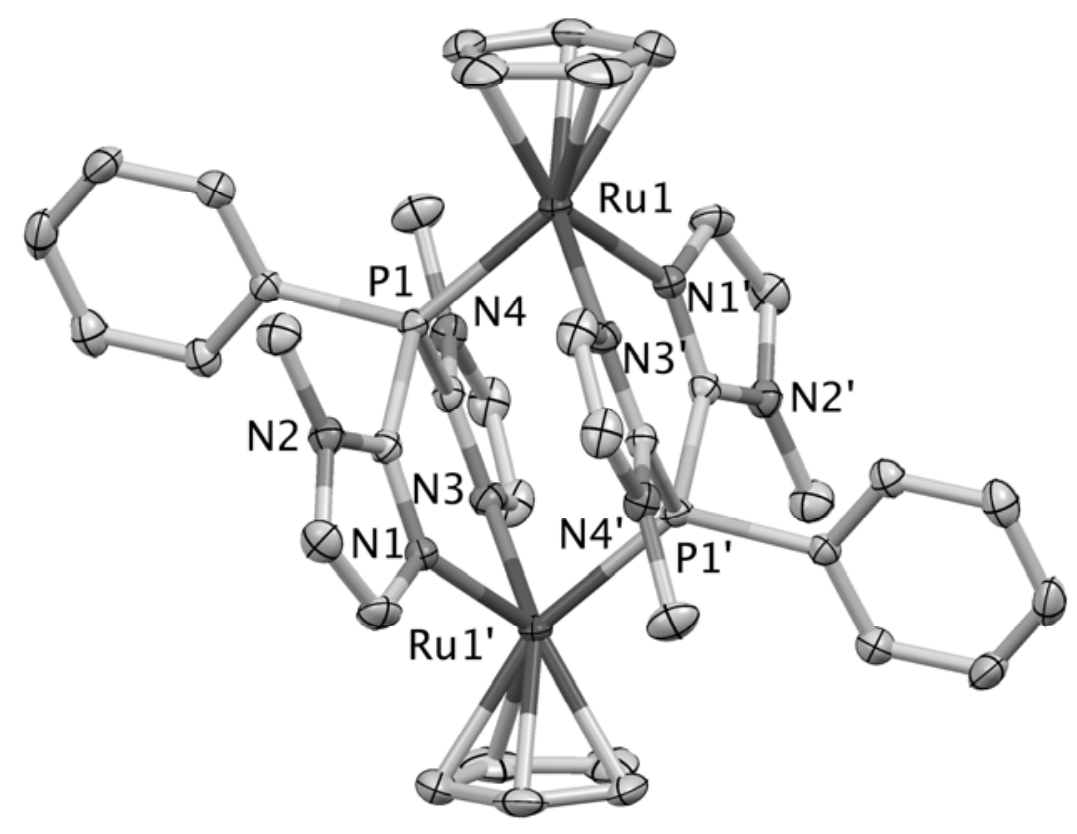

Figure 3. Solid-state structure of the cation $\left[\left\{\mathrm{CpRu}\left(\mu-\kappa^{2}-N, N-\kappa^{\prime 1}-P-2 \mathbf{b}\right)\right\}_{2}\right]^{2+}$ in $\left[\left\{\mathrm{CpRu}\left(\mu-\kappa^{2}-N, N-\right.\right.\right.$ $\left.\left.\left.\kappa^{, 1}-P-2 \mathbf{b}\right)\right\}_{2}\right]\left(\mathrm{PF}_{6}\right)_{2} \mathrm{CH}_{3} \mathrm{CN}\left(7 \mathbf{b} \mathrm{CH}_{3} \mathrm{CN}\right)$. Displacement ellipsoids are drawn at $50 \%$ level. The counter ions, cocrystallized solvent molecules and hydrogen atoms are omitted for clarity.

Red crystals of $\left[\mathrm{CpRu}\left(\kappa^{1} P-\mathbf{3 a}\right)\left(\mathrm{PPh}_{3}\right)\right] \mathrm{Cl} \cdot \mathrm{CH}_{2} \mathrm{Cl}_{2}\left(\mathbf{9} \cdot \mathrm{CH}_{2} \mathrm{Cl}_{2}\right)$ were obtained by crystallisation from chloroform. The compound crystallizes in the monoclinic space group $P 2_{1} / \mathrm{c}$. Two of the three $\mathrm{H}$ atoms of the NH-functionalities of the ligand 3a form intramolecular hydrogen bonds towards $\mathrm{Cl1}$. Another intramolecular hydrogen bond $\mathrm{N}-\mathrm{H}_{\mathrm{A}}{ }^{\cdots} \mathrm{N}_{1 \mathrm{AA}}$ results in the formation of a nearly coplanar six-membered ring (Figure 4). The metric parameters are within the range found in phosphine complexes of the type $\left[\mathrm{CpRu}(\mathrm{L})_{2} \mathrm{Cl}\right] .{ }^{52,53,54,55}$ 


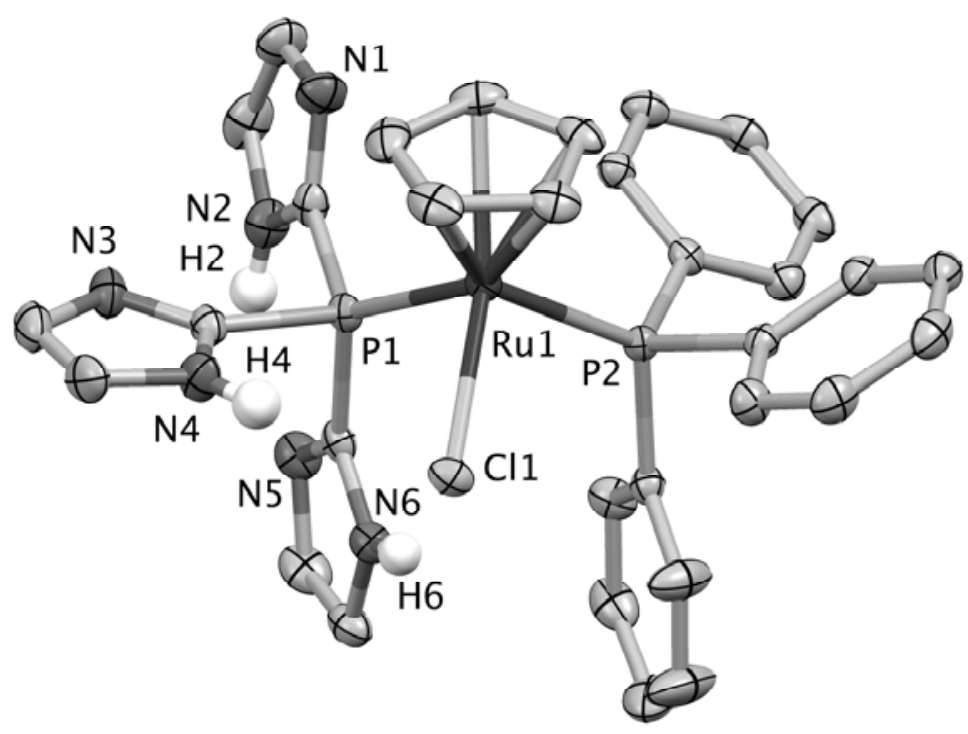

Figure 4. Solid-state structure of $\left[\mathrm{CpRu}\left(\kappa^{1} P-\mathbf{3 a}\right)\left(\mathrm{PPh}_{3}\right)\right] \mathrm{Cl} \cdot \mathrm{CH}_{2} \mathrm{Cl}_{2}\left(\mathbf{9} \cdot \mathrm{CH}_{2} \mathrm{Cl}_{2}\right)$. Displacement ellipsoids are drawn at $50 \%$ level. Hydrogen atoms are drawn at arbitrary radius and non-acidic hydrogen atoms are omitted for clarity.

Table 4. Crystallographic data for $\left[\mathrm{CpRu}(\mathbf{1 a})_{2} \mathrm{Cl}\right] \cdot \mathrm{H}_{2} \mathrm{O}\left(\mathbf{5} \cdot \mathrm{H}_{2} \mathrm{O}\right),\left[\left\{\mathrm{CpRu}\left(\mu-\kappa^{2}-N, N-\kappa^{, 1}-P-\right.\right.\right.$ 2b) $\left.\}_{2}\right]\left(\mathrm{PF}_{6}\right)_{2} \mathrm{CH}_{3} \mathrm{CN}\left(\mathbf{7 b} \mathrm{CH}_{3} \mathrm{CN}\right),\left[\left\{\mathrm{CpRu}\left(\mu-\kappa^{2}-N, N-\kappa{ }^{\prime 1}-P-\mathbf{2 b}\right)\right\}_{2}\right]\left(\mathrm{C}_{6} \mathrm{H}_{5} \mathrm{PO}_{3} \mathrm{H}\right)_{2}\left(\mathrm{C}_{6} \mathrm{H}_{5} \mathrm{PO}_{3} \mathrm{H}_{2}\right)_{2}$, $\left[\mathrm{CpRu}\left(\kappa{ }^{1} \mathrm{P}-\mathbf{3 a}\right)\left(\mathrm{PPh}_{3}\right)\right] \mathrm{Cl} \cdot \mathrm{CH}_{2} \mathrm{Cl}_{2}\left(\mathbf{9} \cdot \mathrm{CH}_{2} \mathrm{Cl}_{2}\right)$ and $\left[\mathrm{CpRu}\left(\mathrm{PPh}_{3}\right)_{2}\right] \mathrm{Cl} \cdot \mathrm{CHCl}_{3}$.

\begin{tabular}{|c|c|c|c|c|c|}
\hline Compound & $5 \cdot \mathrm{H}_{2} \mathrm{O}$ & $7 \mathbf{b} \cdot \mathrm{CH}_{3} \mathrm{CN}$ & $\begin{array}{l}{\left[\{\mathrm{CpRu}(\mathbf{2 b})\}_{2}\right]} \\
\left(\mathrm{C}_{6} \mathrm{H}_{5} \mathrm{PO}_{3} \mathrm{H}\right)_{2}\left(\mathrm{C}_{6} \mathrm{H}_{5} \mathrm{PO}_{3} \mathrm{H}_{2}\right)_{2}\end{array}$ & 9. $\mathrm{CH}_{2} \mathrm{Cl}_{2}$ & $\begin{array}{l}{\left[\mathrm{CpRu}\left(\mathrm{PPh}_{3}\right)_{2}\right] \mathrm{Cl}} \\
\cdot \mathrm{CHCl}_{3}\end{array}$ \\
\hline Empirical formula & $\mathrm{C}_{35} \mathrm{H}_{33} \mathrm{ClN}_{4} \mathrm{OP}, \mathrm{Ru}$ & $\mathrm{C}_{42} \mathrm{H}_{46} \mathrm{~F}_{12} \mathrm{~N}_{10} \mathrm{P}_{4} \mathrm{Ru}$ & $\mathrm{C}_{6} \mathrm{H}_{66} \mathrm{~N}_{8} \mathrm{O}_{1}, \mathrm{P}_{6} \mathrm{Ru}_{2}$ & $\mathrm{C}_{33} \mathrm{H}_{31} \mathrm{Cl}_{3} \mathrm{~N}_{6} \mathrm{P}, \mathrm{Ru}$ & $\mathrm{C}_{4}, \mathrm{H}_{36} \mathrm{Cl}_{4} \mathrm{P}, \mathrm{Ru}$ \\
\hline Formula weight & 724.11 & 1244.91 & 1503.19 & 781.00 & 845.52 \\
\hline Crystal system & Monoclinic & Monoclinic & Triclinic & Monoclinic & Triclinic \\
\hline Space group & $\mathrm{P} 2{ }_{1} / n$ & $\mathrm{P} 2{ }_{1} / c$ & $\mathrm{P}-1$ & $\mathrm{P} 2{ }_{1} / c$ & $\mathrm{P}-1$ \\
\hline a $\lceil\AA\rceil\rceil$ & $9.35991(13)$ & $12.1695(4)$ & $11.35775(17)$ & $14.6359(6)$ & $10.0331(3)$ \\
\hline $\mathrm{b}\lceil\AA\rceil$ & $19.4751(3)$ & $13.8697(6)$ & $12.3482(2)$ & $8.3887(3)$ & $13.8107(5)$ \\
\hline $\mathrm{c}\lceil\AA ̊\rceil$ & $17.2255(3)$ & $13.9362(5)$ & $13.2800(3)$ & $27.1301(12)$ & $14.4657(5)$ \\
\hline$\left.\alpha \Gamma^{\circ}\right\rceil$ & 90.00 & 90.00 & $117.0250(19)$ & 90.00 & $100.141(3)$ \\
\hline$\left.\beta \Gamma^{\circ}\right\rceil$ & $93.3452(13)$ & $96.327(3)$ & $104.5021(15)$ & $96.813(4)$ & $106.935(3)$ \\
\hline$\left.\gamma \Gamma^{\circ}\right\rceil$ & 90.00 & 90.00 & $91.1715(13)$ & 90.00 & $99.411(3)$ \\
\hline Volume $\left\lceil\AA^{3}\right\rceil$ & $3134.61(8)$ & $2337.93(15)$ & $1586.69(5)$ & $3307.4(2)$ & $1837.79(11)$ \\
\hline Z & 4 & 2 & 1 & 4 & 2 \\
\hline Density & 1.534 & 1.768 & 1.573 & 1.568 & 1.528 \\
\hline Absorption & 0.724 & 0.876 & 0.696 & 0.848 & 0.836 \\
\hline $\mathrm{F}(000)$ & 1480 & 1248 & 768 & 1584 & 860 \\
\hline Crystal size $\left[\mathrm{mm}^{3}\right]$ & $0.47 \times 0.11 \times 0.10$ & $0.19 \times 0.14 \times 0.04$ & $0.37 \times 0.23 \times 0.16$ & $0.14 \times 0.07 \times 0.05$ & $0.20 \times 0.12 \times 0.05$ \\
\hline Crystal description & yellow needle & orange plate & yellow block & Orange needle & orange plate \\
\hline $\begin{array}{l}\text { Theta range for } \\
\text { data collection }\left[{ }^{\circ}\right]\end{array}$ & & 2.57 to 30.51 & 2.95 to 36.32 & 2.95 to 29.5 & 2.61 to 30.51 \\
\hline
\end{tabular}




\begin{tabular}{|c|c|c|c|c|c|}
\hline \multirow[t]{3}{*}{ Index ranges } & & $-17<=\mathrm{h}<=17,-$ & $-18<=\mathrm{h}<=18$ & $-18<=\mathrm{h}<=19$ & $-14<=\mathrm{h}<=14$ \\
\hline & & $19<=\mathrm{k}<=19,-$ & $-20<=\mathrm{k}<=20$ & $-11<=\mathrm{k}<=11$ & $-19<=\mathrm{k}<=17$ \\
\hline & & $19<=1<=19$ & $-22<=1<=22$ & $-36<=1<=34$ & $-20<=1<=18$ \\
\hline Reflections & & $24410 *$ & 59543 & 21611 & 20943 \\
\hline \multicolumn{6}{|l|}{ collected } \\
\hline Independent & & $24410 *$ & $15362[\mathrm{R}(\mathrm{int})=0.0247]$ & $7893[\mathrm{R}($ int $)=$ & $11219[\mathrm{R}($ int $)=$ \\
\hline reflections & & & & $0.0406]$ & $0.0328]$ \\
\hline Reflections & & 18628 & 13058 & 6313 & 7958 \\
\hline Criterion for & $>2 \operatorname{sigma}(\mathrm{I})$ & $>2 \operatorname{sigma}(\mathrm{I})$ & $>2 \operatorname{sigma}(\mathrm{I})$ & $>2 \operatorname{sigma}(\mathrm{I})$ & $>2 \operatorname{sigma}(\mathrm{I})$ \\
\hline Completeness to & & $99.9 \%$ to $30.51^{\circ}$ & $99.8 \%$ to $36.32^{\circ}$ & $99.74 \%$ to $26.32^{\circ}$ & $99.9 \%$ to $30.51^{\circ}$ \\
\hline Absorption & & Semi-empirical & Semi-empirical from & Semi-empirical & Semi-empirical \\
\hline correction & & from equivalents & equivalents & from equivalents & from equivalents \\
\hline Max. and min. & & 0.9658 and 0.8980 & 0.8968 and 0.8362 & 1.0000 and & 0.9594 and 0.8045 \\
\hline transmission & & & & 0.8779 & \\
\hline Data / restraints / & & $24410 / 0 / 320$ & $15362 / 0 / 412$ & $7893 / 0 / 406$ & $11219 / 0 / 442$ \\
\hline Goodness-of-fit on & 1.097 & 1.032 & 1.116 & 1.021 & 0.899 \\
\hline Final $\mathrm{R}$ indices & & $\mathrm{R} 1=0.0454, \mathrm{wR} 2$ & $\mathrm{R} 1=0.0271, \mathrm{wR} 2=$ & $\mathrm{R} 1=0.0376, \mathrm{wR} 2$ & $\mathrm{R} 1=0.0360, \mathrm{wR} 2$ \\
\hline$[\mathrm{I}>2 \operatorname{sigma}(\mathrm{I})]$ & & $=0.1232$ & 0.0772 & $=0.0805$ & $=0.0627$ \\
\hline \multirow[t]{2}{*}{$\mathrm{R}$ indices (all data) } & & $\mathrm{R} 1=0.0624, \mathrm{wR} 2$ & $\mathrm{R} 1=0.0336, \mathrm{wR} 2=$ & $\mathrm{R} 1=0.0528, \mathrm{wR} 2$ & $\mathrm{R} 1=0.0601, \mathrm{wR} 2$ \\
\hline & & $=0.1303$ & 0.0786 & $=0.0838$ & $=0.0657$ \\
\hline Largest diff. peak & & 1.109 and -0.844 & 0.797 and -0.595 & 0.714 and -0.649 & 0.715 and -0.853 \\
\hline CCDC number & & 837344 & 828860 & 820763 & 828861 \\
\hline
\end{tabular}

* Due to the twin integration, there are no independent reflections.

\subsection{Catalytic trials with CpRu-based complexes of PN ligands}

Grotjahn et al. described the catalytic activity of the complex $\left[\mathrm{CpRu}(\mathrm{L})_{2}\left(\mathrm{NCCH}_{3}\right)\right] \mathrm{PF}_{6}$ with the $\mathrm{PN}$ ligand 2-diphenylphosphino-6-tert-butylpyridine (L) in the hydration of several terminal alkynes to give up to $99.9 \%$ yield within $3 \mathrm{~h}$ with a catalyst loading of just $2 \mathrm{~mol}-\%{ }^{25}$

We used a protocol established for the catalytic hydration of ruthenium(II) pyridinyl phosphine complexes and $\left[\mathrm{CpRu}\left(\mathrm{NCCH}_{3}\right)_{3}\right] \mathrm{PF}_{6}$ as well as $\left[\mathrm{CpRu}\left(\mathrm{C}_{10} \mathrm{H}_{8}\right)\right] \mathrm{PF}_{6}$ for the preparation of compounds of the type $\left[\mathrm{CpRu}(\mathrm{L})_{2}\left(\mathrm{NCCH}_{3}\right)\right] \mathrm{PF}_{6}{ }^{25,56}$ The corresponding $\mathrm{CpRu}$-precursor and two equivalents of the corresponding ligand were stirred at $60{ }^{\circ} \mathrm{C}$ in an oil bath over night (monitored by ${ }^{31} \mathrm{P}$ NMR, see ESI). The results of the various catalytic hydration reactions with different ligands were unexpectedly disappointing (for details see ESI). None of the investigated complexes showed substantial catalytic activity in the hydration of 1-octyne. The highest conversion with $9 \%$ after $22 \mathrm{~h}$ at $60{ }^{\circ} \mathrm{C}$ was found in a trial with $\left[\mathrm{CpRu}\left(\mathrm{C}_{10} \mathrm{H}_{8}\right)\right] \mathrm{PF}_{6}$ and $4-\mathrm{MIP}^{\mathrm{iPrNMe}}(\mathbf{1 i})$ at a catalyst loading of $5 \mathrm{~mol} \%$. 


\section{Conclusions}

We prepared CpRu-complexes with imidazole-based PN ligands. Three types of coordination modes for the PN ligands have been found in the corresponding CpRu complexes: $\kappa^{1} P$-monodentate, $\kappa^{2} P, N$-, $\kappa^{2} N, N$ - and $\kappa^{3} N, N, N$ - chelating and $\mu-\kappa P: \kappa^{2} N, N$-brigding. We have screened 11 imidazole-based PN ligands in the $\mathrm{CpRu}(\mathrm{II})$-catalysed hydration of 1-octyne. Although the observed conversion rates are low to zero, some complexes show high selectivity for the formation of aldehyde over ketone. When poly(imidazolyl) ligands are used, the formation of coordinatively saturated complexes seems to prevent catalytic activity. Furthermore, in compounds with imidazol-2-ylphosphine ligands formation of 1,2phosphinylimidazole by $\mathrm{P}-\mathrm{C}$ bond cleavage in the coordination sphere of the metal has been observed. This may be another deactivation path of these compounds thus limiting their use in catalytic applications. 


\section{Graphical Abstract}
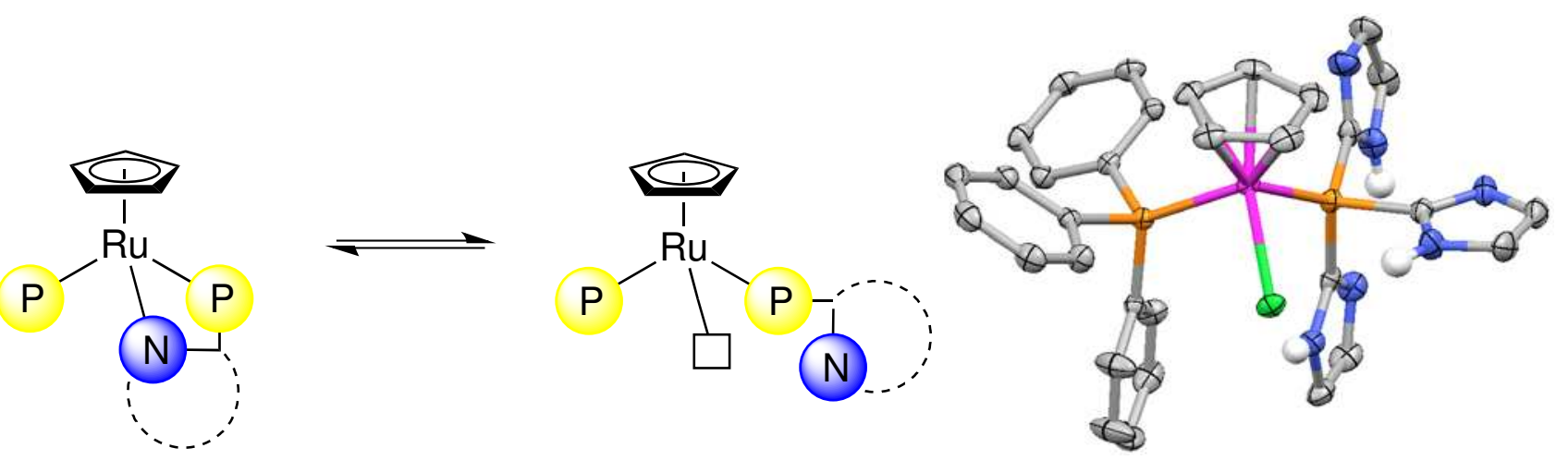

\section{Textual Abstract}

Piano-stool complexes of cyclopentadienyl ruthenium(II) with imidazole-based PN ligands have been screened for their catalytic activity in the hydration of 1-octyne. PN ligands used were imidazol-2-yl, 4-yl and -5-yl phosphines. The catalytic trials in the presence of $\left[\mathrm{CpRu}\left(\mathrm{C}_{10} \mathrm{H}_{8}\right)\right] \mathrm{PF}_{6}$ showed low activity in the hydration of 1-octyne to octanal. Deactivation of the $\mathrm{CpRu}(\mathrm{II})$ is attributed to two deactivation pathways. (i) Formation of coordinatively saturated complexes by polyimidazolyl ligands; Different types of coordination modes for the polyimidazolyl PN ligands were observed: $\kappa^{1} P$-monodentate, $\kappa^{2} P, N$-, $\kappa^{2} N, N$ - and $\kappa^{3} N, N, N$ - chelating and $\mu-\kappa P: \kappa^{2} N, N$-brigding. (ii) P-C Bond cleavage in imidazol-2yl phosphine ligands. 


\title{
Ruthenium Piano-Stool Complexes Bearing Imidazole-Based PN Ligands
}

\author{
Peter C. Kunz ${ }^{*, a}$, Indre Thiel, ${ }^{a, b}$ Anna Louisa Noffke, ${ }^{a, c}$ Guido J. Reiß, ${ }^{a, *}$ Fabian Mohr ${ }^{d, \hat{b}}$ and \\ Bernhard Spingler ${ }^{e, t}$
}

[a] Institut für Anorganische Chemie und Strukturchemie, Heinrich-Heine-Universität, Universitätsstr. 1, D-40225 Düsseldorf, Germany, Fax: +49 211 8112287, E-mail: peter.kunz@uni-duesseldorf.de

[b] Current address: Leibniz-Institut für Katalyse e. V. an der Universität Rostock, Albert-Einstein-Str. 29a, D-18059 Rostock, Germany.

[c] Current address: Department of Chemistry, University of Warwick, Gibbet Hill Road, Coventry, CV4 7AL, UK.

[d] Bergische Universität Wuppertal, Fachbereich C - Anorganische Chemie, Gaußstr. 20, D-42119 Wuppertal, Germany.

[e] Anorganisch-Chemisches Institut, Universität Zürich-Irchel, Winterthurerstr. 190, CH-8057 Zürich, Switzerland.

[†] X-ray structure analysis. 


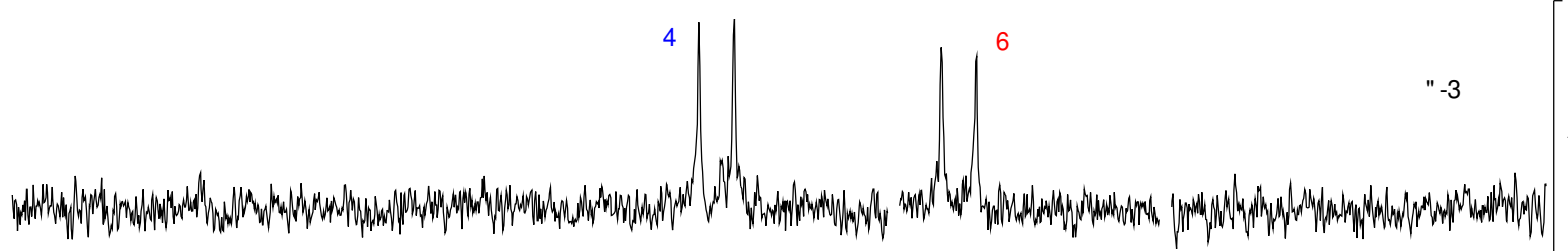

"-2

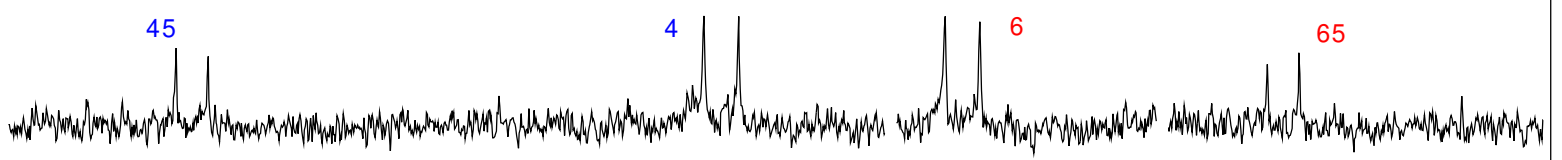

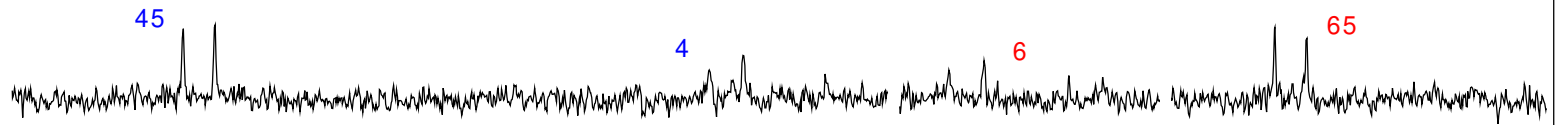
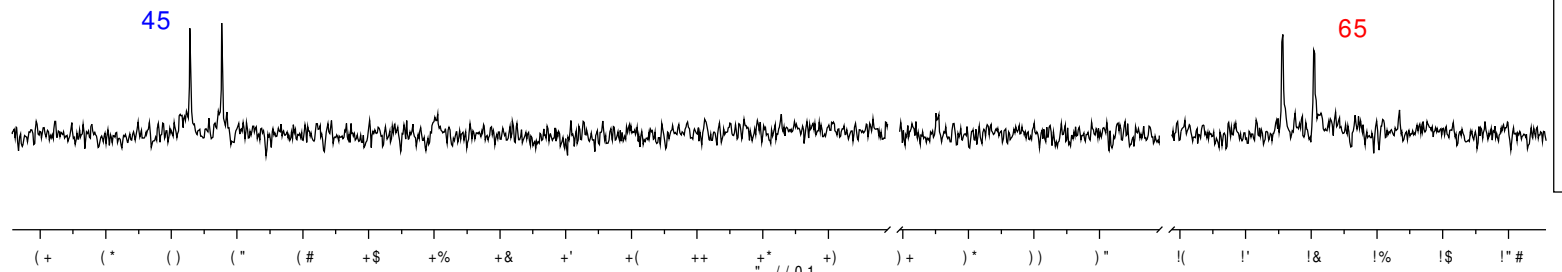

Figure S1. ${ }^{31} \mathrm{P}\left\{{ }^{1} \mathrm{H}\right\}$ NMR spectra of the reaction of $\left[\mathrm{CpRu}\left(\mathrm{PPh}_{3}\right)(\kappa P-\mathbf{1 d}) \mathrm{Cl}\right]$ (4) with $\mathrm{TlNO}_{3}$ in $\left(\mathrm{CD}_{3}\right)_{2} \mathrm{CO}$ gives $\left[\mathrm{CpRu}\left(\mathrm{PPh}_{3}\right)\left(\kappa^{2} P N-\mathbf{1 d}\right)\right] \mathrm{NO}_{3}$.

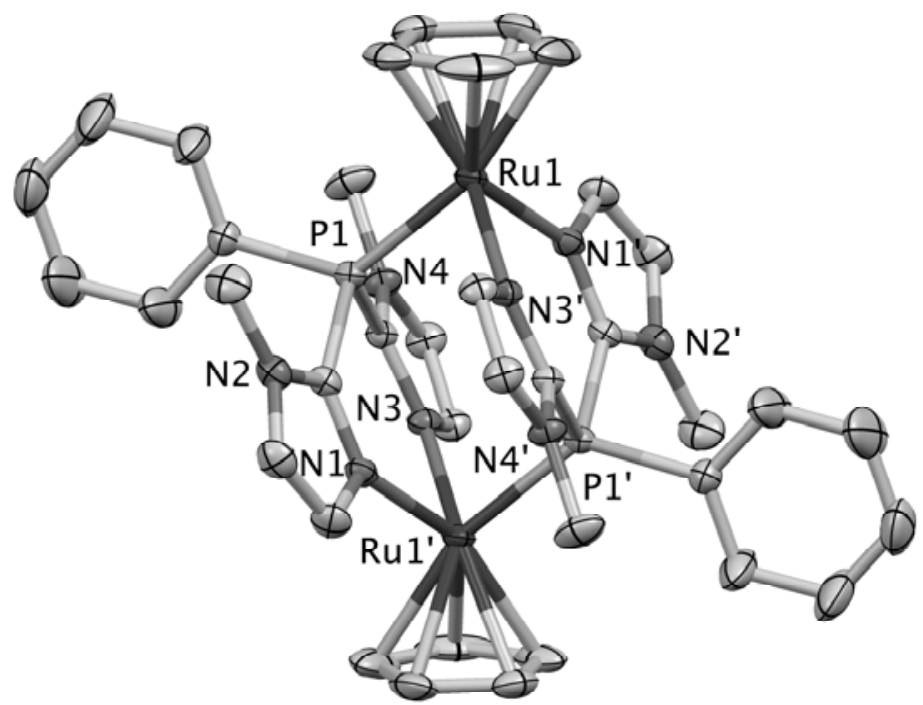


Figure S2. Solid-state structure of the cation $\left[\left\{\mathrm{CpRu}\left(\mu-\kappa^{2}-N, N-\kappa^{, 1}-P-\mathbf{2 b}\right)\right\}_{2}\right]^{2+}$ in $\left[\left\{\mathrm{CpRu}\left(\mu-\kappa^{2}-N, N-\right.\right.\right.$ $\left.\left.\left.\kappa^{\prime 1}-P-2 \mathbf{b}\right)\right\}_{2}\right]\left(\mathrm{C}_{6} \mathrm{H}_{5} \mathrm{PO}_{3} \mathrm{H}\right)_{2}\left(\mathrm{C}_{6} \mathrm{H}_{5} \mathrm{PO}_{3} \mathrm{H}_{2}\right)_{2}$. Displacement ellipsoids are drawn at $50 \%$ level. The counter ions and hydrogen atoms are omitted for clarity.

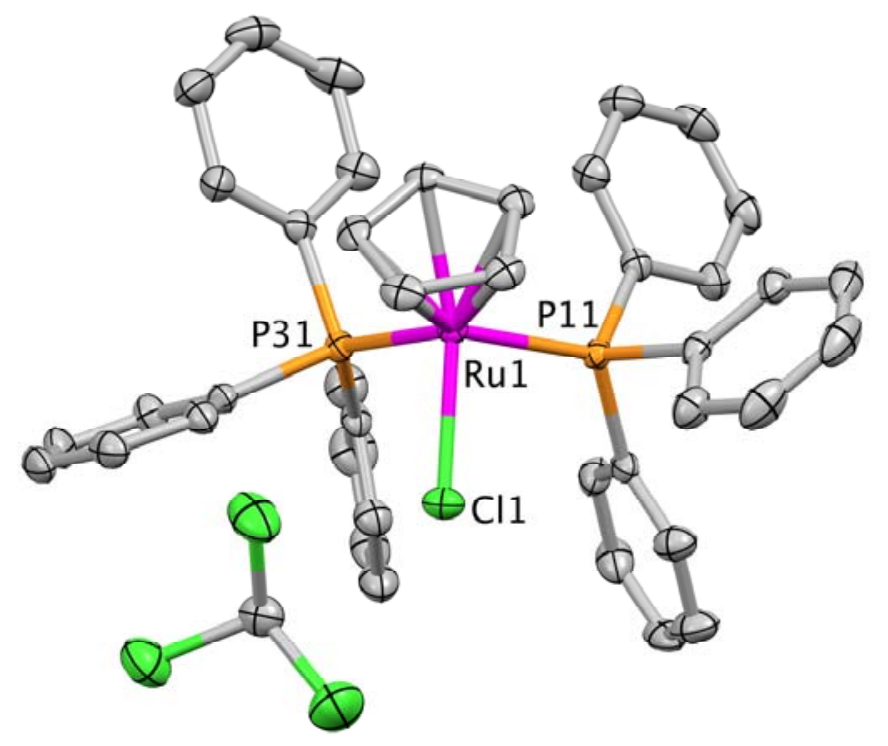

Figure S3. Molecular structure of the solvate $\left[\mathrm{CpRu}\left(\mathrm{PPh}_{3}\right)_{2} \mathrm{Cl}\right] \cdot \mathrm{CHCl}_{3}$. Displacement ellipsoids are drawn at $50 \%$ level and hydrogen atoms are omitted for clarity. For the solvent free structure see reference 55 .

Table S1. ${ }^{31} \mathrm{P}\left\{{ }^{1} \mathrm{H}\right\}$ NMR shifts of the ligands (L) and the respective ruthenium complexes $(\mathrm{C})$ as well as the coordination shift $\Delta \delta=\delta_{\mathrm{C}}-\delta_{\mathrm{L}}\left(\right.$ in methanol- $\left.d_{4}\right)$.

\begin{tabular}{|c|c|c|c|}
\hline Ligand & $\delta_{\mathrm{L}}\left({ }^{31} \mathrm{P}\right) / \mathrm{ppm}$ & $\delta_{\mathrm{C}}\left({ }^{31} \mathbf{P}\right) / \mathbf{p p m}$ & $\Delta \delta\left({ }^{31} \mathrm{P}\right) / \mathrm{ppm}$ \\
\hline $2-\mathrm{MIP}^{\mathrm{H}}$ (1a) & -23.8 & $48.8 ; 116.2$ & 72.6 \\
\hline $2-\mathrm{MIP}^{\mathrm{NMe}}(\mathbf{1 b})$ & -29.6 & 34.7 & 64.3 \\
\hline 2-BIP ${ }^{\mathrm{NMe}}(\mathbf{2} \mathbf{b})$ & -61.3 & 11.7 & 73.0 \\
\hline $2-\mathrm{TIP}^{\mathrm{NMe}}(\mathbf{3 b})$ & -90.1 & 0.4 & 90.5 \\
\hline 2-MIP ${ }^{\mathrm{diPhNMe}}(\mathbf{1} \mathbf{c})$ & -28.7 & 38.5 & 67.2 \\
\hline $4-\mathrm{MIP}^{\mathrm{NMe}}(\mathbf{1 h})$ & -24.8 & 24.8 & 49.6 \\
\hline 4-MIP ${ }^{\mathrm{iPr}}(\mathbf{1 d})$ & -30.6 & 29.3 & 60.0 \\
\hline 4-MIP ${ }^{\mathrm{iPrNMe}}$ (1i) & -24.4 & 31.3 & 55.7 \\
\hline 4-MIP $\mathrm{M}^{\mathrm{tBu}}(\mathbf{1 e})$ & -29.9 & 30.0 & 59.9 \\
\hline
\end{tabular}




\begin{tabular}{lccc}
\hline $4-\mathrm{MIP}^{\mathrm{tBuNMe}}(\mathbf{1 j})$ & -30.4 & - & - \\
$4-\mathrm{MIP}^{\mathrm{Ph}}(\mathbf{1 f})$ & -29.3 & 34.7 & 64.0 \\
\hline
\end{tabular}

Table S2. Preformed ruthenium complexes and their in situ catalytic activity in the hydration of 1octyne to 1-octanal.

\begin{tabular}{clll}
\hline entry & \multicolumn{1}{c}{ Precursor } & \multicolumn{1}{c}{ Ligand } & Conversion [\% (h)] \\
\hline 1 & {$\left[\mathrm{CpRu}\left(\mathrm{CH}_{3} \mathrm{CN}\right)_{3}\right] \mathrm{PF}_{6}$} & $2-\mathrm{MIP}^{\mathrm{H}}(\mathbf{1 a})$ & $0(22)$ \\
2 & {$\left[\mathrm{CpRu}\left({\text { naphthaline })] \mathrm{PF}_{6}}\right.\right.$} & $2-\mathrm{MIP}^{\mathrm{H}}(\mathbf{1 a})$ & $0(22)$ \\
3 & {$\left[\mathrm{CpRu}\left(\mathrm{NCCH}_{3}\right)_{3}\right] \mathrm{PF}_{6}$} & $2-\mathrm{MIP}^{\mathrm{NMe}}(\mathbf{1 b})$ & $0(22)$ \\
4 & {$[\mathrm{CpRu}($ naphthaline $)] \mathrm{PF}_{6}$} & $2-\mathrm{MIP}^{\mathrm{NMe}}(\mathbf{1 b})$ & $0(22)$ \\
5 & {$[\mathrm{CpRu}($ naphthaline $)] \mathrm{PF}_{6}$} & $2-\mathrm{BIP}^{\mathrm{NMe}}(\mathbf{2 b})$ & $0(22)$ \\
6 & {$[\mathrm{CpRu}($ naphthaline $)] \mathrm{PF}_{6}$} & $2-\mathrm{TIP}^{\mathrm{NMe}}(\mathbf{3 b})$ & $0(22)$ \\
7 & {$[\mathrm{CpRu}($ naphthaline $)] \mathrm{PF}_{6}$} & $2-\mathrm{MIP}^{\mathrm{diPhNMe}}(\mathbf{1 c})$ & $1(24)$ \\
8 & {$[\mathrm{CpRu}($ naphthaline $)] \mathrm{PF}_{6}$} & $4-\mathrm{MIP}^{\mathrm{NMe}}(\mathbf{1 h})$ & $0(22)$ \\
9 & {$[\mathrm{CpRu}($ naphthaline $)] \mathrm{PF}_{6}$} & $4-\mathrm{MIP}^{\mathrm{iPr}}(\mathbf{1 d})$ & $0(22)$ \\
10 & {$[\mathrm{CpRu}($ naphthaline $)] \mathrm{PF}_{6}$} & $4-\mathrm{MIP}^{\mathrm{iPrNMe}}(\mathbf{1 i})$ & $9(22)$ \\
11 & {$\left[\mathrm{CpRu}(\mathrm{NCCH})_{3}\right] \mathrm{PF}_{6}$} & $4-\mathrm{MIP}^{\mathrm{iPrNMe}}(\mathbf{1 i})$ & $0(22)$ \\
12 & {$[\mathrm{CpRu}($ naphthaline $)] \mathrm{PF}_{6}$} & $4-\mathrm{MIP}^{\mathrm{tBu}}(\mathbf{1 e})$ & $2(24)$ \\
13 & {$[\mathrm{CpRu}($ naphthaline $)] \mathrm{PF}_{6}$} & $4-\mathrm{MIP}^{\mathrm{tBuNMe}}(\mathbf{1 j})$ & $0(22)$ \\
14 & {$[\mathrm{CpRu}($ naphthaline $)] \mathrm{PF}_{6}$} & $4-\mathrm{MIP}^{\mathrm{Ph}}(\mathbf{1 f})$ & $0(22)$ \\
\hline
\end{tabular}

\section{Supporting Experimentals}

Synthesis of 4,5-diiodoimidazole 57,58

Imidazole $(8.4 \mathrm{~g}, 0.12 \mathrm{~mol})$ and sodium hydroxide $(14 \mathrm{~g}, 0.35 \mathrm{~mol})$ are dissolved in $0.4 \mathrm{~L}$ water in an 1 L round bottom flask. Potassium iodide ( $80 \mathrm{~g}, 0.48 \mathrm{~mol})$ and iodine $(55 \mathrm{~g}, 0.22 \mathrm{~mol})$ are dissolved in 0.2 L water. This solution is added drop wise to the imidazole / sodium hydroxide mixture at room temperature. A white solid precipitates and the solution is stirred over night. Acetic acid and sodium thiosulfate are added until the solution is clear and neutral. The white solid is filtered and washed with water. Recrystallization from ethanol leads to fine white crystals. (16 g, $41 \%)$. ${ }^{1} \mathrm{H}$ NMR (200 MHz, methanol- $\left.d_{4}\right): \delta=7.79(\mathrm{~s}, 1 \mathrm{H}, \mathrm{CH})$.

Synthesis of 4,5-diiodo-2-isopropylimidazole ${ }^{57}$

2-Isopropylimidazole (11 g, $0.10 \mathrm{~mol})$ and sodium hydroxide $(14 \mathrm{~g}, 0.35 \mathrm{~mol})$ are dissolved in $0.4 \mathrm{~L}$ water in a $1 \mathrm{~L}$ round bottom flask. Potassium iodide $(80 \mathrm{~g}, 0.48 \mathrm{~mol})$ and iodine $(55 \mathrm{~g}, 0.22 \mathrm{~mol})$ are 
dissolved in $0.2 \mathrm{~L}$ water. This solution is added drop wise to the imidazole / sodium hydroxide mixture at room temperature. A white solid precipitates and the solution is stirred over night. Acetic acid and sodium thiosulfate are added until the solution is clear and neutral. The yellow solid is filtered and washed with water. Recrystallization from ethanol leads to fine white crystals. (16 g, 44 \%). ${ }^{1} \mathrm{H}-\mathrm{NMR}$ (200 MHz, methanol- $\left.d_{4}\right): \delta=1.30\left(\mathrm{~d}, 6 \mathrm{H}, \mathrm{CH}_{3}\right), 3.05$ (m, 1H, CH). EI MS (methanol): $m / z=362\left[\mathrm{M}^{+}\right]$, $235\left[\mathrm{M}^{+}-\mathrm{I}\right]$.

Synthesis of 4,5-diiodo-2-tert-butylimidazole ${ }^{57}$

2-tert-Butylimidazole $(2.0 \mathrm{~g}, 16 \mathrm{mmol})$ and sodium hydroxide $(2.0 \mathrm{~g}, 50 \mathrm{mmol})$ are dissolved in $100 \mathrm{~mL}$ water in an $500 \mathrm{~mL}$ round bottom flask. Potassium iodide $(13 \mathrm{~g}, 78 \mathrm{mmol})$ and iodine $(8.1 \mathrm{~g}, 32 \mathrm{mmol})$ are dissolved in $40 \mathrm{~mL}$ water. This solution is added drop wise to the imidazole / sodium hydroxide mixture at room temperature. A white solid precipitates and the solution is stirred over night. Acetic acid and sodium thiosulfate are added until the solution is clear and neutral. The yellow solid is filtered and washed with water. Recrystallization from ethanol leads to fine white crystals. $(2.7 \mathrm{~g}, 44 \%) .{ }^{1} \mathrm{H}$ NMR (200 MHz, methanol- $\left.d_{4}\right): \delta=1.35$ (s, 9H, $\mathrm{CH}_{3}$ ). EI MS (methanol): $m / z=376\left[\mathrm{M}^{+}\right], 193\left[\mathrm{M}^{+}-\mathrm{I}-\right.$ $\mathrm{tBu}$.

Synthesis of 1-methyl-4,5-diiodoimidazole ${ }^{59}$

4,5-Diiodoimidazole (14 g, $40 \mathrm{mmol})$ is dissolved in thf. An equimolar amount of potassium tertbutoxide $(5.0 \mathrm{~g}, 44 \mathrm{mmol})$ is added to the solution at $0{ }^{\circ} \mathrm{C}$ and the solution is stirred for $1 \mathrm{~h}$ at that temperature. An equimolar amount of methyl iodide $(2.7 \mathrm{~mL}, 44 \mathrm{mmol})$ is added drop wise to the solution at $0{ }^{\circ} \mathrm{C}$. A white solid precipitates and the otherwise clear solution is stirred at room temperature over night. The white solid is filtered and washed with dichloromethane. The solvent is removed from the filtrate and the resulting yellow solid is dissolved in dichloromethane and filtered. The solvent is removed from the filtrate and the solid is dried under vacuum. (14 g, $94 \%) .{ }^{1} \mathrm{H}$ NMR $\left(200 \mathrm{MHz}, \mathrm{CDCl}_{3}\right): \delta=3.73\left(\mathrm{~s}, 3 \mathrm{H}, \mathrm{CH}_{3}\right), 7.65(\mathrm{~s}, 1 \mathrm{H}, \mathrm{CH})$.

Synthesis of 1-methyl-4,5-diiodo-2-isopropylimidazole ${ }^{59}$

4,5-Diiodo-2-isopropylimidazole $(8.0 \mathrm{~g}, 22 \mathrm{mmol})$ is dissolved in thf. An equimolar amount of potassium tert-butoxide $(2.5 \mathrm{~g}, 22 \mathrm{mmol})$ is added to the solution at $0{ }^{\circ} \mathrm{C}$ and the solution is stirred for 1 $\mathrm{h}$ at that temperature. An equimolar amount of methyl iodide $(1.4 \mathrm{~mL}, 22 \mathrm{mmol})$ is added drop wise to the solution at $0{ }^{\circ} \mathrm{C}$. A white solid precipitates and the solution turns pink, later on yellow. The solution is stirred at room temperature over night. The white solid is filtered and washed with dichloromethane. The solvent is removed from the filtrate and the resulting brown oil is dissolved in dichloromethane and filtered. The solvent is removed from the filtrate and the oil is dried under vacuum. $(7.9 \mathrm{~g}, 97 \%) .{ }^{1} \mathrm{H}$ NMR (200 MHz, $\left.\mathrm{CDCl}_{3}\right): \delta=1.32\left(\mathrm{~d}, 6 \mathrm{H}, \mathrm{CH}_{3}\right), 3.05(\mathrm{~m}, 2 \mathrm{H}, \mathrm{CH}), 3.65\left(\mathrm{~s}, 3 \mathrm{H}, \mathrm{CH}_{3}\right)$. EI MS (methanol): $m / z=376\left[\mathrm{M}^{+}\right], 361\left[\mathrm{M}^{+}-\mathrm{CH}_{3}\right], 249\left[\mathrm{M}^{+}-\mathrm{I}\right]$. 
4,5-Diiodo-2-tert-butylimidazole $(2.25 \mathrm{~g}, 6.00 \mathrm{mmol})$ is dissolved in thf. An equimolar amount of potassium tert-butoxide $(0.7 \mathrm{~g}, 6 \mathrm{mmol})$ is added to the solution at $0{ }^{\circ} \mathrm{C}$ and the solution is stirred for 1 $\mathrm{h}$ at that temperature. An equimolar amount of methyl iodide $(0.9 \mathrm{~mL}, 6 \mathrm{mmol})$ is added drop wise to the solution at $0{ }^{\circ} \mathrm{C}$. A white solid precipitates and the solution turns orange-pink, later on yellow. The solution is stirred at room temperature over night. The white solid is filtered and washed with dichloromethane. The solvent is removed from the filtrate and the resulting yellow oil is dissolved in dichloromethane and filtered. The solvent is removed from the filtrate and the yellow solid is dried under vacuum. (2.1 g, 85 \%). ${ }^{1} \mathrm{H}-\mathrm{NMR}\left(200 \mathrm{MHz}, \mathrm{CDCl}_{3}\right): \delta=1.45\left(\mathrm{~s}, 9 \mathrm{H}, \mathrm{CH}_{3}\right), 3.82\left(\mathrm{~s}, 3 \mathrm{H}, \mathrm{CH}_{3}\right)$. EI MS (methanol): $m / z=390\left[\mathrm{M}^{+}\right], 375\left[\mathrm{M}^{+}-\mathrm{CH}_{3}\right], 263\left[\mathrm{M}^{+}-\mathrm{I}\right], 207\left[\mathrm{M}^{+}-\mathrm{CH}_{3}-\mathrm{I}\right]$.

\section{Synthesis of 1-methyl-4,5-diphenylimidazole ${ }^{59}$}

4,5-Diphenylimidazole $(6.6 \mathrm{~g}, 30 \mathrm{mmol})$ is dissolved in thf. An equimolar amount of potassium tertbutoxide $(3.4 \mathrm{~g}, 30 \mathrm{mmol})$ is added to the solution at $0{ }^{\circ} \mathrm{C}$ and the solution is stirred for $1 \mathrm{~h}$ at that temperature. The solution turns deep blue, later on pink with a white solid precipitating. An equimolar amount of methyl iodide $(1.9 \mathrm{~mL}, 30 \mathrm{mmol})$ is added drop wise to the solution at $0{ }^{\circ} \mathrm{C}$. The solution is stirred at room temperature over night. The solvent is removed and the white/pink residue is dissolved in $80 \mathrm{~mL}$ dichloromethane and filtered. The solvent from the orange filtrate is removed resulting in a light pink solid, which is dried under vacuum. (6.0 g, 89 \%). ${ }^{1} \mathrm{H} \mathrm{NMR}\left(200 \mathrm{MHz}, \mathrm{CDCl}_{3}\right): \delta=3.54$ (s, $\left.3 \mathrm{H}, \mathrm{CH}_{3}\right), 7.14-7.55(\mathrm{~m}, 10 \mathrm{H}, \mathrm{Ph}), 7.64(\mathrm{~s}, 1 \mathrm{H}, \mathrm{CH})$. EI MS (methanol): $m / z=234\left[\mathrm{M}^{+}\right]$. 
1-Methyl-4,5-diiodoimidazole $(6.5 \mathrm{~g}, 19 \mathrm{~mol})$ is dissolved in thf. One equivalent of ethyl magnesium bromide ( $3 \mathrm{M}$ in ether) is slowly added to the solution at $0{ }^{\circ} \mathrm{C}$. A white solid forms immediately. The solution is stirred for $1 \mathrm{~h}$, than water $(0.4 \mathrm{~mL})$ is added to the solution. The solution is stirred at room temperature over night. An equal volume of an ammonium chloride solution is added to the reaction mixture. The aqueous phase is washed with dichloromethane $(3 \mathrm{x})$ and the combined organic phase is washed with a saturated sodium chloride solution $(3 \mathrm{x})$. The organic phase is then dried over sodium sulfate, filtered and the solvent removed. The resulting yellow oil is dried under vacuum. (3.5 g, $89 \%$ ). ${ }^{1} \mathrm{HNMR}\left(200 \mathrm{MHz}, \mathrm{CDCl}_{3}\right) \delta=3.71\left(\mathrm{~s}, 3 \mathrm{H}, \mathrm{CH}_{3}\right), 6.99(\mathrm{~s}, 1 \mathrm{H}, \mathrm{CH}), 7.35(\mathrm{~s}, 1 \mathrm{H}, \mathrm{CH})$.

Synthesis of 1-methyl-4-iodo-2-isopropylimidazole ${ }^{59}$

1-Methyl-4,5-diiodo-2-isopropylimidazole (4.2 g, $11 \mathrm{mmol})$ is dissolved in thf. One equivalent of ethyl magnesium bromide ( $3 \mathrm{M}$ in ether) is slowly added to the solution at $0{ }^{\circ} \mathrm{C}$. The clear solution is stirred for $1 \mathrm{~h}$, then water $(0.4 \mathrm{~mL})$ is added to the solution and a white solid forms. The solution is stirred at room temperature over night. An equal volume of an ammonium chloride solution is added to the reaction mixture. The aqueous phase is washed with dichloromethane $(3 \mathrm{x})$ and the combined organic phase is washed with a saturated sodium chloride solution $(3 \mathrm{x})$. The organic phase is then dried over sodium sulfate, filtered and the solvent removed. The resulting yellow oil is dried under vacuum. (2.5 g, $91 \%$ ). ${ }^{1} \mathrm{H}-\mathrm{NMR}\left(200 \mathrm{MHz}, \mathrm{CDCl}_{3}\right): \delta=1.31\left(\mathrm{~d}, 6 \mathrm{H}, \mathrm{CH}_{3}\right), 3.00(\mathrm{~m}, 1 \mathrm{H}, \mathrm{CH}), 6.87(\mathrm{~s}, 1 \mathrm{H}, \mathrm{CH})$. EI MS (methanol): $m / z=250\left[\mathrm{M}^{+}\right], 235\left[\mathrm{M}^{+}-\mathrm{CH}_{3}\right], 107\left[\mathrm{M}^{+}-\mathrm{CH}_{3}-\mathrm{I}\right]$.

Synthesis of 1-methyl-4-iodo-2-tert-butylimidazole ${ }^{59}$

1-Methyl-4,5-diiodo-2-tert-butylimidazole ( $2 \mathrm{~g}, 5 \mathrm{mmol})$ is dissolved in thf. One equivalent of ethyl magnesium bromide ( $3 \mathrm{M}$ in ether) is slowly added to the solution at $0{ }^{\circ} \mathrm{C}$. The clear solution is stirred for $1 \mathrm{~h}$, then water $(0.2 \mathrm{~mL})$ is added to the solution and a white solid forms. The solution is stirred at room temperature over night. An equal volume of an ammonium chloride solution is added to the reaction mixture. The aqueous phase is washed with dichloromethane $(3 \mathrm{x})$ and the combined organic phase is washed with a saturated sodium chloride solution $(3 \mathrm{x})$. The organic phase is then dried over sodium sulfate, filtered and the solvent removed. The resulting yellow solid is dried under vacuum. (1.4 g, 99 \%). ${ }^{1} \mathrm{HNMR}\left(200 \mathrm{MHz}, \mathrm{CDCl}_{3}\right): \delta=1.46\left(\mathrm{~s}, 9 \mathrm{H}, \mathrm{CH}_{3}\right), 3.77\left(\mathrm{~s}, 3 \mathrm{H}, \mathrm{CH}_{3}\right), 6.87(\mathrm{~s}, 1 \mathrm{H}, \mathrm{CH}) . \mathrm{EI}$ MS (methanol): $m / z=264\left[\mathrm{M}^{+}\right], 249\left[\mathrm{M}^{+}-\mathrm{CH}_{3}\right], 121\left[\mathrm{M}^{+}-\mathrm{I}\right]$. 


\section{References}

${ }^{1}$ M. Berthelot, Ann. Chim. Phys. 67 (1863) 52.

${ }^{2}$ M. G. Kutscheroff, Chem. Ber. 14 (1881) 1540-1542.

${ }^{3}$ R. J. Thomas, K. N. Champbell, G. F. Hennion, J. Am. Chem. Soc. 60 (1938) 718-720.

${ }^{4}$ M. G. Kutscheroff, Chem. Ber. 42 (1909) 2759-2762.

${ }^{5}$ M. Nishizawa, H. Imagawa, H. Yamamoto, Org. Biomol. Chem. 8 (2010) 511-521.

${ }^{6}$ Y.Fukuda, K. Utimoto, J. Org. Chem. 56 (1991) 3729-3731.

${ }^{7}$ J. Halpern, B. R. James, A. L. W. Kemp, J. Am. Chem. Soc. 83 (1961) 4097-4098.

${ }^{8}$ J. Halpern, B. R. James, A. L. W. Kemp, J. Am. Chem. Soc. 88 (1966) 5142-5147.

${ }^{9}$ T. M. M. Khan, S. B. Halligudi, S. Shukla, J. Mol. Catal. 58 (1990) 299-305.

${ }^{10}$ J. Blum, H. Huminer, H. Alper, J. Mol. Catal. 75 (1992) 153-160.

${ }^{11}$ W. Baidossi, M. Lahav, J. Blum, J. Org. Chem. 62 (1997) 669-672.

${ }^{12}$ W. Hiscox, P. W. Jennings, Organometallics 9 (1990) 1997-1999.

${ }^{13}$ L. Hintermann, A. Labonne, Synthesis 8 (2007) 1121-1150.

${ }^{14}$ X. Jin, T. Oishi, K. Yamaguchi, N. Mizuno, Chem. - Eur. J. 17 (2011) 1261-1267.

15 M. Beller, J. Seayad, A. Tillack, H. Jiao, Angew. Chem. Int. Ed. 43 (2004) 3368-3398.

${ }^{16}$ A. Finiels, P. Geneste, F. Marichez, P. Moreau, Catal. Lett. (1989) 181-184.

${ }^{17}$ M. Tokunaga, Y. Wakatsuki, Angew. Chem. Int. Ed. 37 (1998) 2867-2869.

${ }^{18}$ M. Tokunaga, T. Suzuki, N. Koga, T. Fukushima, A Horiuchi, Y. Wakatsuki, J. Am. Chem. Soc. 123 (2001) 11917-11924.

${ }^{19}$ L. Hintermann, Top. Organomet. Chem. 31 (2010) 123-155.

${ }^{20}$ T. Suzuki, M. Tokunaga, Y. Wakatsuki, Org. Lett. 3 (2001) 735-737.

${ }^{21}$ B. M. Rosner, B. Schink, J. Bacteriol. 177 (1995) 5767-5772.

${ }^{22}$ G. B. Seiffert, G. M. Ullmann, A. Messerschmidt, B. Schink, P. M. H. Kroneck, O. Einsle, Proc. Natl. Acad. Sci. USA 104 (2007) 3073-3077.

${ }^{23}$ S. Antony, C. A. Bayse, Organometallics 28 (2009) 4938-4944.

${ }^{24}$ R. Z. Liao, J. G. Yu, F. Himo, Proc. Natl. Acad. Sci. USA. 107 (2010) 22523-22527.

${ }^{25}$ F. Boeck, T. Kribber, L. Xiao, L. Hintermann, J. Am. Chem. Soc. 133 (2011) 8138-8141.

${ }^{26}$ L. Hintermann, T. T. Dang, A. Labonne, T. Kribber, L. Xiao, P. Naumov, Chem. - Eur. J. 15 (2009) 7167-7179.

${ }^{27}$ D. B. Grotjahn, D. A. Lev, J. Am. Chem. Soc. 126 (2004) 12232-12233.

${ }^{28}$ D. B. Grotjahn, C. D. Incarvato, A. L. Rheingold, Angew. Chem. Int. Ed. 40 (2001) 3884-3887.

${ }^{29}$ R. N. Nair, P. J. Lee, A. L. Rheingold, D. B. Grotjahn, Chem. -Eur. J. 16 (2010) 7992-7995.

${ }^{30}$ A. Labonne, T. Kribber, L. Hintermann, Org. Lett. 8 (2006) 5853-5856. 
${ }^{31}$ a) D. B. Grotjahn, E. J. Kragulj, C. D. Zeinalipour-Yazdi, V. Miranda-Soto, D. A. Lev, A. L. Cooksy, J. Am. Chem. Soc, 130 (2008) 10860-10861. b) D. B. Grotjahn, V. Miranda-Soto, E. J. Kragulj, D. A. Lev, G. Erdogan, X. Zeng, A. L. Cooksy, J. Am. Chem. Soc, 130 (2008) 20-21. c) D. B. Grotjahn, Chem. - Eur. J. 11 (2005) 7146-7153.

${ }^{32}$ A. A Tolmachev, A. A. Yurchenko, A. S. Merculov, M. G. Semenova, E. V. Zarudnitskii, V. V. Ivanov, A. M. Pinchuk, Heteroat. Chem. 10 (1999) 585-597.

${ }^{33}$ P. C. Kunz, G. J. Reiß, W. Frank, W. Kläui, Eur. J. Inorg. Chem. (2003) 3945-3951.

${ }^{34}$ U. Beckmann, D. Süslüyan, P. C. Kunz, Phosphorus, Sulfur Silicon Relat. Elem. (2011) Manuscript ID: 547892 .

${ }^{35}$ M. I. Bruce, C. Hameister, Inorg. Synth. 21 (1982) 78-80

${ }^{36}$ E. P. Kündig, F. R. Monnier, Adv. Synth. Catal. 346 (2004) 901-904.

${ }^{37}$ CrysAlis Pro Softwaresystem. Oxford Diffraction Ltd, 171.32, Oxford, UK, 2007.

${ }^{38}$ A. Altomare, M. C. Burla, M. Camalli, G. L. Cascarano, C. Giacovazzo, A. Guagliardi, A. G. G. Moliterni, G. Polidori, R. Spagna, J. Appl. Crystallogr. 32 (1999) 115-119.

${ }^{39}$ G.M. Sheldrick, Acta Crystallogr., Sect. A, 64 (2008) 112-122.

${ }^{40}$ A. L. Spek, J. Appl. Crystallogr. 36 (2003) 7-13.

${ }^{41}$ O. V. Dolomanov, L. J. Bourhis, R. J. Gildea, J. A. K. Howard, H. Puschmann, J. Appl. Cryst. 42 (2009) 339-341.

${ }^{42}$ D. B. Grotjahn, J. E. Kraus, H. Amouri, M.-N. Rager, A. L. Cooksy, A. J. Arita, S. A. Cortes-Llamas, A. A. Mallari, A. G. DiPasquale, C. E. Moore, L. M. Liable-Sands, J. D. Golen, L. N. Zakharov, A. L. Rheingold, J. Am. Chem. Soc. 132 (2010) 7919-7934.

${ }^{43}$ A. Caballero, F. A. Jalón, B. R. Manzano, G. Espino, M. Pérez-Manrique, A. Mucientes, F. J. Poblete, M. Maestro, Organometallics 23 (2004) 5694-5706.

${ }^{44}$ P. C. Kunz, W. Kläui, Collect. Czech. Chem. Commun. 72 (2007) 492-502.

${ }^{45}$ P. C. Kunz, M. U. Kassack, A. Hamacher, B. Spingler, Dalton Trans. (2009) 7741-7747.

${ }^{46}$ P. C. Kunz, W. Huber, A. Rojas, U. Schatzschneider, B. Spingler, Eur. J. Inorg. Chem. (2009) 53585366.

${ }^{47}$ P. C. Kunz, W. Huber, B. Spingler, J. Chem. Crystallogr. 41 (2011) 105-110.

${ }^{48}$ A. M. Kluwer, I. Ahmad, J. N. H. Reek, Tetrahedron Lett. 48 (2007) 2999-3001.

${ }^{49}$ A. A. Tolmachev, A. A. Yurchenko, A. B. Rozhenko, M. G. Semenova, Zh. Obshch. Khim. 63 (1993) 1911-1913.

${ }^{50}$ P. Kumar, A. K. Singh, S. Sharma, D. S. Pandey. J. Organomet. Chem. 694 (2009) 3643-3652.

${ }^{51}$ P. Espinet, P. Goomez-Elipe, F. Villafane, J. Organomet. Chem. 450 (1993) 145-150.

${ }^{52}$ A. Romerosa, T. Campos-Malpartida, C. Lidrissi, M. Saoud, M. Serrano-Ruiz, M. Peruzzini, J. A. Garrido-Cárdenas F. Garciá-Maroto, Inorg. Chem. 45 (2006) 1289-1298. 
${ }^{53}$ C. A. Mebi, B. J. Frost, Organometallics 24 (2005) 2339-2346.

${ }^{54}$ M. Abou Rida, C. Copéret, A. K. Smith, J. Organomet. Chem. 628 (2001) 1-10.

${ }^{55}$ M. I. Bruce, F. S. Wong, B. W. Skelton, A. H. White, J. Chem. Soc. Dalton Trans. (1981) 13981405.

${ }^{56}$ L. Hintermann, L. Xiao, A. Labonne, U. Englert, Organometallics 28 (2009) 5739-5748.

${ }^{57}$ S.K. Mal, L. Bohe, S. Achab, Tetrahedron 64 (2008) 64, 5904-5914.

${ }^{58}$ G. Desforges, C. Bossert, C. Montange, J. Benoit, Synlett. 7, (2004) 1306-1308.

${ }^{59}$ C. J. Lovely, H. Du, R. Sivappa, M. R. Bhandari, Y. He, H. V. R. Dias, J. Org. Chem. 72 (2007) 3741-3749. 